\title{
Water circulation and impact on water quality in the southwest of Efate Island, Vanuatu
}

\author{
Gaelle Faivre ${ }^{\mathrm{a}, \mathrm{c}, \mathrm{d}, *}$, Erie Sami $^{\mathrm{b}}$, Brendan Mackey ${ }^{\mathrm{c}}$, Rodger Tomlinson ${ }^{\mathrm{a}}$, Hong Zhang ${ }^{\mathrm{d}}$, \\ Krishna Kumar Kotra ${ }^{\mathrm{e}}$, Jim Aimbie ${ }^{\mathrm{b}}$, Michael Maniel ${ }^{\mathrm{e}}$, Guilherme Vieira da Silva ${ }^{\mathrm{a}}$, Emily Rand ${ }^{\mathrm{f}}$ \\ ${ }^{a}$ Griffith Centre for Coastal Management, Griffith University, Gold Coast, Australia \\ b Department of Water Resources, Ministry of Lands and Natural Resources, Port Vila, Vanuatu \\ c Griffith Climate Change Response Program, Griffith University, Gold Coast, Australia \\ d School of Engineering and Built Environment, Griffith University, Gold Coast, Australia \\ ${ }^{\text {e }}$ School of Agriculture, Geography, Environment, Ocean and Natural Sciences, The University of the South Pacific, Emalus Campus, Port Vila, Vanuatu \\ ${ }^{\mathrm{f}}$ UNICEF, Port Vila, Vanuatu
}

\section{A R T I C L E I N F O}

\section{Keywords:}

Residence time

Lagoon

E. coli

Vanuatu

Water quality

\begin{abstract}
A B S T R A C T
In Small Island Developing States (SIDS), water pollution is not monitored or assessed frequently enough to fully understand the processes, impacts of water quality issues and what solutions are available This study investigated flushing time in Erakor lagoon and Port Vila Bay, Vanuatu using a numerical model developed in Delft3D. Microbial contamination by Escherichia coli was detected in multiple locations in the lagoon system with counts exceeding thresholds related to human health concerns. Modelling demonstrated a poor flushing time overall with a further decrease as the influence of waves and wind increased, especially in Vila Bay. Sea level rise resulted in an increase in flushing time downstream of the lagoon near the open sea, while with a decrease upstream and in Vila Bay. Based on these results, we recommend long-term continuous monitoring and identification of higher risks areas to prioritise decisions around wastewater management.
\end{abstract}

\section{Introduction}

Small Island Developing States (SIDS), such as Vanuatu, face multiple challenges in terms of environment and development including coral reef deterioration, damage to infrastructure, loss of coastal land and managing waste and growing population (Graham et al., 2020; Devlin et al., 2020). Vanuatu is considered one of the world's most vulnerable countries to natural hazards (Heintz et al., 2018) and inherently vulnerable to climate change impacts (Nurse et al., 2014). Vanuatu's is exposed to sea level rise impacts and other natural disasters and is vulnerable due in part to being comprised of many small remote islands with remote communities, its low level of economic development and the concentration of settlements and infrastructure in the coastal zone (Garschagen et al., 2016; Mackey and Ware, 2018; Boateng, 2010).

SIDS are also vulnerable to climate change impacts including sea level rise (Nurse et al., 2014) which can reduce the water quality from salinisation and increase coastal flooding (Thomas et al., 2020). These impacts are added to the multiple pressures facing SIDs and coastal systems. Vanuatu's population has increased by $66 \%(2000-2020)$ with
$24.4 \%$ of the population now living in urban locations (United Nations, Department of Economic and Social Affairs, Population Division, 2019) with projections suggesting this could increase by $88 \%$ by 2050 (United Nations, Department of Economic and Social Affairs, Population Division, 2019). The population growth rate on Efate Island is almost double this national rate with the majority of the growth occurring in the periurban fringes of Port Vila municipality, Efate (Komugabe-Dixson et al., 2019; Zari et al., 2020). Port Vila, the nation's capital, has more than a quarter of Vanuatu's total population and the growth rate is estimated to be up to $8 \%$ per annum (Zari et al., 2020). Increasing population growth and tourism in Pacific SIDS (Gheuens et al., 2019) results in more marine pollution, wastewater discharge and land degradation and therefore an increase in the need for improved sanitation systems. The increase in coastal population growth and tourism in Pacific SIDS (Gheuens et al., 2019) results in increased demand for sanitation system from the additional marine pollution, wastewater discharge and land degradation. This increase in coastal population and the inadequate sewage infrastructure is one of the main drivers of marine pollution across the Pacific SIDS (McEvoy et al., 2017). This is the case of many south Pacific

\footnotetext{
* Corresponding author at: School of Engineering and Built Environment, Griffith University, Gold Coast, Australia.

E-mail address: g.faivre@griffith.edu.au (G. Faivre).
} 


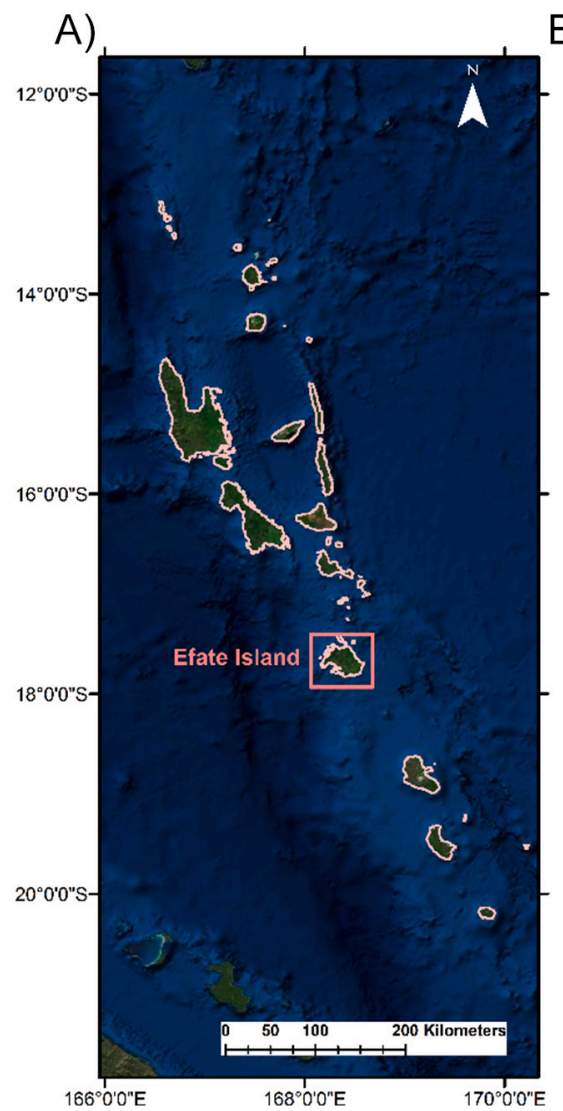

B)

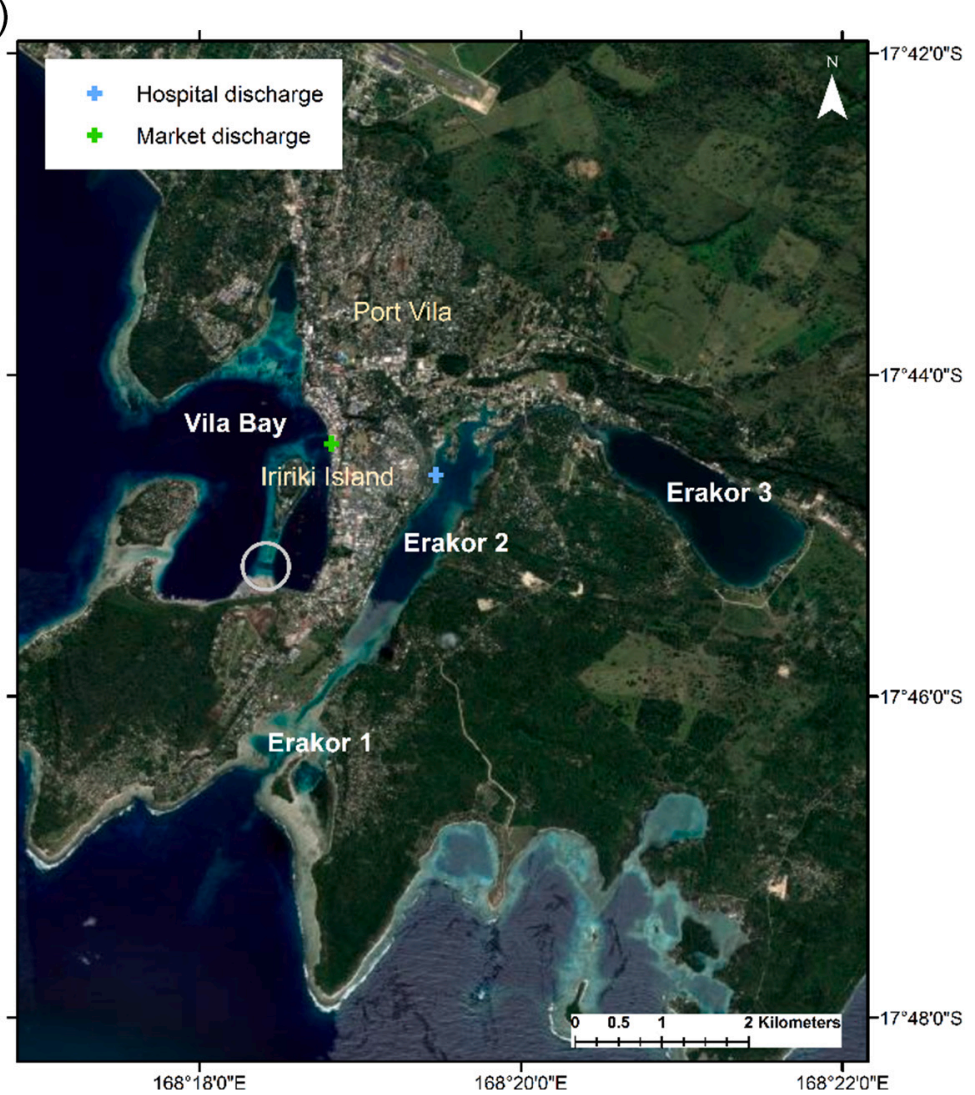

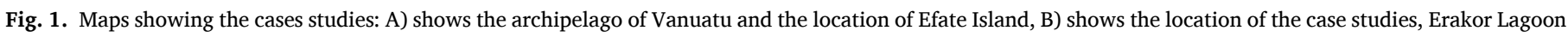

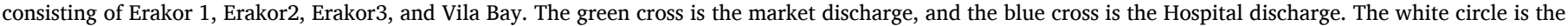

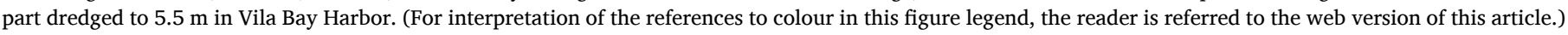

islands where wastewater is discharged directly into the ocean with little or no treatment (Graves et al., 2021) which may affect coral reefs and coastal ecosystems (United Nations, 2004). Done and Navin (1990) noted that the two main threats to the coral reefs of Vanuatu are siltation and eutrophication caused by domestic sewage discharged into reef waters. Tourist resorts in Vanuatu are concentrated along the coast, where limited or no wastewater treatment or management systems are in place (SOPAC, 2007). In Port Vila, the associated growth in population and development has resulted in wastewater being discharged into Port Vila Bay and Erakor Lagoon (Fig. 1) yet there are no effective wastewater management systems in place.

In Vanuatu, sewage contamination is also a serious health issue (Devlin et al., 2020) with many of the discharged wastes sourced from uncontrolled and unregulated piping and drainage (SOPAC, 2007; SPREP, 2016), And many businesses and houses having a directdischarge sewage system (SOPAC, 2007). Sewage contamination is an additional stress on coral reef ecosystems, exacerbating climate change impacts and further highlighting the need to protect coastal water quality. Other pressures that may also be impacting on the water quality of the Bay include dredging and industrial runoff. In 2017, the channel on the southern end of the inner harbor in Vila Bay was dredged to $5.5 \mathrm{~m}$ depth with a channel $50 \mathrm{~m}$ wide, $200 \mathrm{~m}$ long (Hall, 2021).

To date, assessments of water quality and wastewater in Vanuatu coastal waters (Graham et al., 2020; Devlin et al., 2020; SPREP, 2016) with have shown that water quality issues are close to shore, though a lack of long-term data make it difficult to identify scale of change. Faecal contamination from sewage is often the reason for high bacterial levels (Hart et al., 2020). Total coliform, E. coli and Enterococci are the three types of bacteria tested as indicators of the presence of faecal material within Port Vila Harbor (Department of Geology, Mines \& Water
Resources, Government of Vanuatu, 2018; Taillardat et al., 2020). Such pathogens may pose health risk to people fishing, swimming and bathing in a water body. It was found that many businesses and houses in Port Vila Town still continue to empty human waste directly into the drainage system. Water quality issues became highly publicised when recreational activities including swimming, fishing, snorkelling were banned within Port Vila Bay in July 2018 due to high levels of bacteria with total coliform and $E$. coli (Department of Geology, Mines, and Water Resources, Government of Vanuatu, 2018). In 2021, the swimming ban was lifted in some parts of Vila harbor, though all swimming is banned during rainfall events. Erakor lagoon system is also highly used by locals and tourist for recreational activities There is also a further lack of water quality data in Erakor lagoon system (DGMWR, 2008) and therefore water pollution might go unnoticed, and might be unsafe for any recreational activities as found in Vila Harbor.

The effective management of reef-lagoon systems such as Erakor Lagoon requires a detailed understanding of the dominant circulation patterns that drive key processes such as sediment transport, biochemical cycling and spatial ecology (Lowe et al., 2010). The circulation can be driven by waves, tide, wind or buoyancy forcing (Lowe et al., 2010; Sous et al., 2017; Dumas et al., 2012). An understanding of circulation and the physical dispersal patterns of the wastewater are fundamental to managing water discharge and water quality in the system. However, knowledge of the flushing patterns and residence time within Erakor Lagoon and Port Vila Harbor is limited, and the factors influencing circulation patterns are unknown. Exposure to potential pollutants could be identified with a more informed understanding of the circulation and hydrodynamics of Erakor lagoon and Port Villa Bay. Furthermore, modelling of pollution transport would provide information on the likely impact of pollution on coastal coral reefs and human health. 


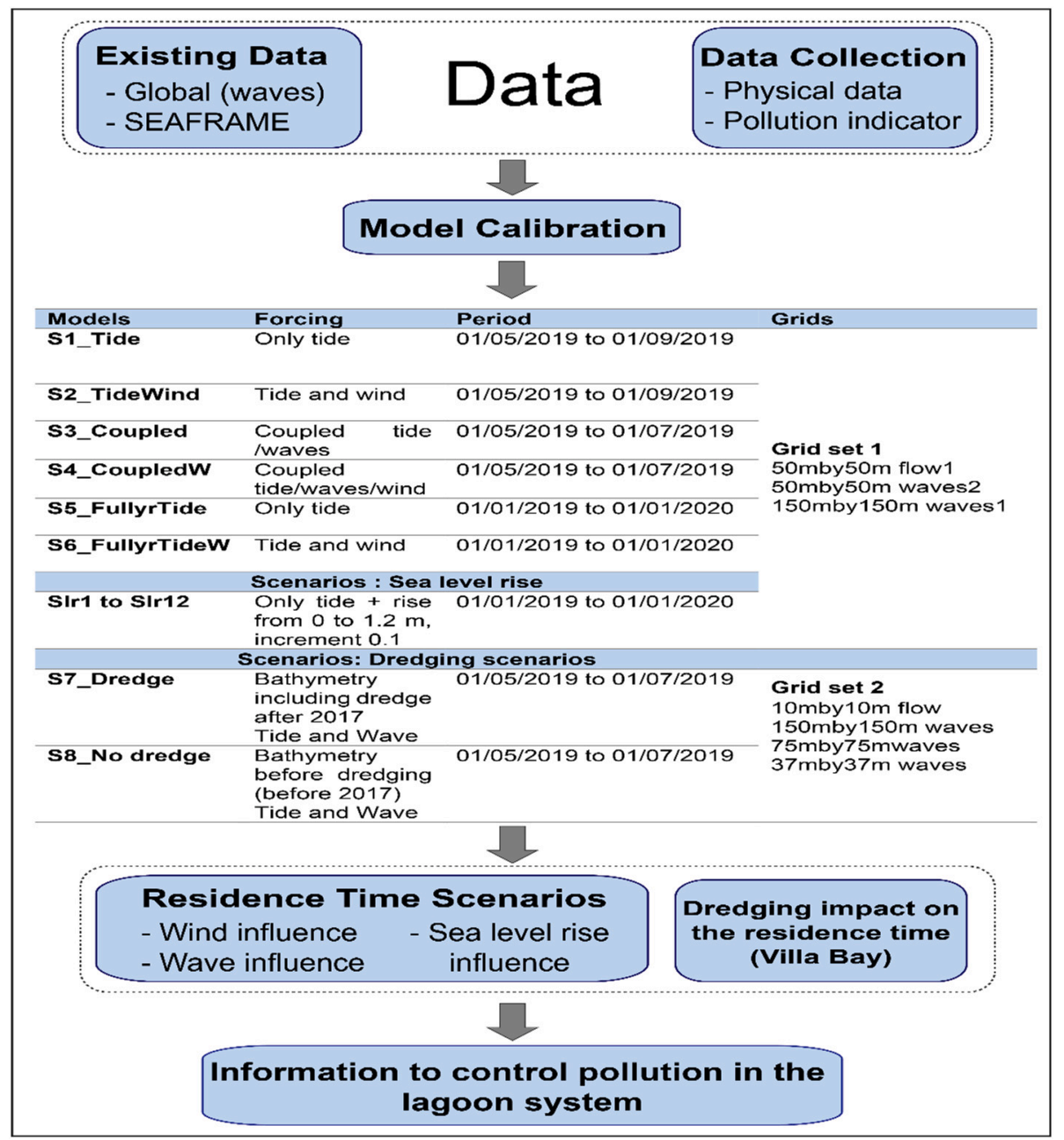

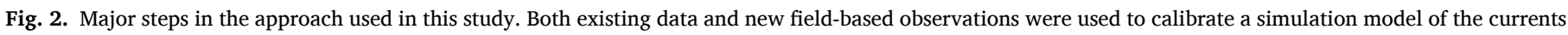

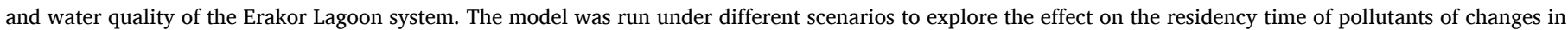
wind, wave, and sea level rise. The results provided evidence in support of recommendations for water quality management planning.

The aim of this study, therefore, was to understand the fate of pollutants and their residence time within Port Vila Bay, where health impacts from wastewater discharge are well documented, and in Erakor Lagoon where there is little understanding of the impact of wastewater discharge on water quality. Given ongoing climate change impacts, we also modelled the potential impacts of project sea level rise under a range of scenarios. It was also anticipated that this study could generate information to support the development of water quality management action plans for the bay and lagoon which are currently lacking.

\section{The study area}

Vanuatu is an archipelago comprising 83 small islands in the South Pacific Ocean of mostly volcanic origin with 65 of them inhabited. There are about $1300 \mathrm{~km}$ between the most northern and southern islands and the total area is around $12,189 \mathrm{~km}^{2}$. Shefa is one of the six provinces of Vanuatu located in the centre of the country and includes the island of Efate which is volcanic and limestone/raised reef in origin. Erakor Lagoon system is located in the East side of Port Vila in Efate Island. Erakor Village has a long coastline with extensive reefs and seagrass meadows that are habitats for dugong and sea turtles (McEvoy et al., 2017). Most of the hotels and infrastructures are located on the shores of the lagoon. The Hospital is also located close to the lagoon with wastewater pipes connecting them. Erakor lagoon consists of three lagoons referred to as Erakor lagoon 1, Erakor lagoon 2 (known as
Ekasuvat Lagoon) and Erakor lagoon 3 (known as Emtem Lagoon) (Fig. 1). Erakor lagoon 2 is around $3 \mathrm{~km}$ long, $0.5 \mathrm{~km}$ wide and $10 \mathrm{~m}$ deep and has an entrance to the ocean at the southern end and a second outlet that leads to Erakor Lagoon 3, which is around $2.5 \mathrm{~km}$ long, 0.75 $\mathrm{km}$ wide and $6 \mathrm{~m}$ deep (Carter, 1990). A $1 \mathrm{~km}$ long by $60 \mathrm{~m}$ wide channel links them. Erakor Lagoon 2 is linked to Erakor Lagoon 1 by a $750 \mathrm{~m}$ channel long and around 100 m wide. Vila Bay contains Port Vila Harbor, Ifira Island and Iririki Island. Vanuatu has two seasons, summer from November to April which is hot and humid and winter from April to October which is cool and dry. The average wave directions and wind directions are coming from the South-East (Faivre et al., 2019) and stronger winds and waves are generally from May to September.

Semi-treated hospital waste released in the lagoon (blue cross in Fig. 1) could degrade the water quality.

\section{Methodology and approach}

Modelling of pollution transport would provide information on the likely impact of pollution on coastal coral reefs and human health. Data on waves, tides and currents were collected by Griffith University to calibrate a numerical model for estimating pollution residence time inside Vila Bay and the Erakor Lagoon system and the dispersion of pollutants in the lagoons. The residence time characterizes the local transport rate and is calculated as the flushing time measured with passive tracers. Then, scenarios were used to examine the potential 
Table 1

Sea level projection for three emissions scenarios (Source: Pacific Climate Change Program, 2013).

\begin{tabular}{lllll}
\hline Scenarios & $\begin{array}{l}2030 \\
(\mathrm{~cm})\end{array}$ & $\begin{array}{l}2050 \\
(\mathrm{~cm})\end{array}$ & $\begin{array}{l}2070 \\
(\mathrm{~cm})\end{array}$ & $\begin{array}{l}2090 \\
(\mathrm{~cm})\end{array}$ \\
\hline $\begin{array}{l}\text { Very low emissions scenario } \\
\quad(\mathrm{RCP} 2.6)\end{array}$ & $8-19$ & $15-31$ & $20-45$ & $25-59$ \\
$\begin{array}{l}\text { Low emissions scenario } \\
\quad(\mathrm{RCP} 4.5)\end{array}$ & $8-18$ & $15-32$ & $23-49$ & $30-67$ \\
$\begin{array}{l}\text { Medium emissions scenario } \\
\quad(\mathrm{RCP6})\end{array}$ & $8-18$ & $15-31$ & $23-48$ & $32-69$ \\
$\begin{array}{l}\text { High emission scenario } \\
\quad(\mathrm{RCP} 8.5)\end{array}$ & $8-18$ & $17-35$ & $29-59$ & $42-89$ \\
\hline
\end{tabular}

impacts on the residence time of pollutants in the lagoon system from climate change-driven sea level rise and associated shifts in wind and waves. From these scenario analyses, recommendations were developed for wastewater management plans.

In this study we applied a 2D flow model coupled with waves to the complex bathymetry of Erakor Lagoon and Mele Bay including Vila Harbor using Delft 3D software. Fig. 2 presents an overview of the major steps in our approach.

\subsection{Available data}

The Pacific Sea Level Monitoring (PSLM) operates under the Climate and Oceans Support Program in the Pacific (COSPPac). Vanuatu is among twelve participating countries in the program called Sea Level Fine Resolution Acoustic Measuring Equipment (SEAFRAME). A tide gauge was installed in 1993 under this program in Port Vila (longitude: $168^{\circ} 17^{\prime} 35^{\prime \prime} \mathrm{E}$; latitude: $17^{\circ} 45^{\prime} 41^{\prime \prime}$ ) (Fig. 4). In addition, other variables are recorded including atmospheric pressure, air, water temperatures, winds speed and direction. The tides in Port Vila are mainly semi-diurnal with a tidal range varying from about 1.6 at spring tide to $0.6 \mathrm{~m}$ at neap tide.
Global water levels projections were available for four emissions scenarios (Table 1, Pacific-Australia Climate Change Science and Adaptation Planning Program, 2013). Sea level rise in Vanuatu is projected to range from $18 \mathrm{~cm}$ to $89 \mathrm{~cm}$ between 2030 and 2090 compared to the baseline period of 1986-2005.

Currents in the lagoon can also be influenced by winds (Graham et al., 2020) with stronger winds expected during May to September and weaker winds typically occurring during November to April (Graham et al., 2020). An existing wind station at the airport show winds coming from the southeast and lower winds during the summer season from December to March as shown in Fig. 3. This wind station is used later to force our models.

No permanent wave buoys have been deployed in Vanuatu to collect wave data. However, global wave data from WAVEWATCH III (WW3) model of Tolman (2009) were available. WW3 is a third-generation wave model hosted by NOAA/NCEP who make available a dataset of parametric and spectral wave data from 1979 to the present and available model grid points around Efate Island are shown in Faivre et al. (2019). For the southwest of Efate, the average significant wave height is coming from the southeast (Fig. 3).

\subsection{Data collection}

3.2.1. Measurements of physical parameters (waves, currents and salinity)

Waves were measured outside the reef as shown in Fig. 4 with a spotter wave buoy (Sofarocean, 2021) placed at around $34 \mathrm{~m}$ depth at the longitude: $168.3056^{\circ}$ and at the latitude $-17.7815^{\circ}$ from $07 / 05$ / 2019 to 30/05/2019. A pressure sensor (RBR duets 3 ) measuring waves and water levels was placed at the entrance of Erakor Lagoon (Lon: $168.30427^{\circ}$; Lat: $-17.773697^{\circ}$ ) from $04 / 10 / 2018$ to $10 / 10 / 2018$ (red cross Fig. 4) and on the reef (Lon: 168.30592; Lat: 17.77809) from 07/ 05/2019 to 30/05/2019 (red thick cross, Fig. 4).

Four Marotte HS tilt-drag type current meters were placed at four strategic locations from $08 / 05 / 2019$ to $30 / 05 / 2019$ to measure the current at the seabed in order to calibrate the hydrodynamic model
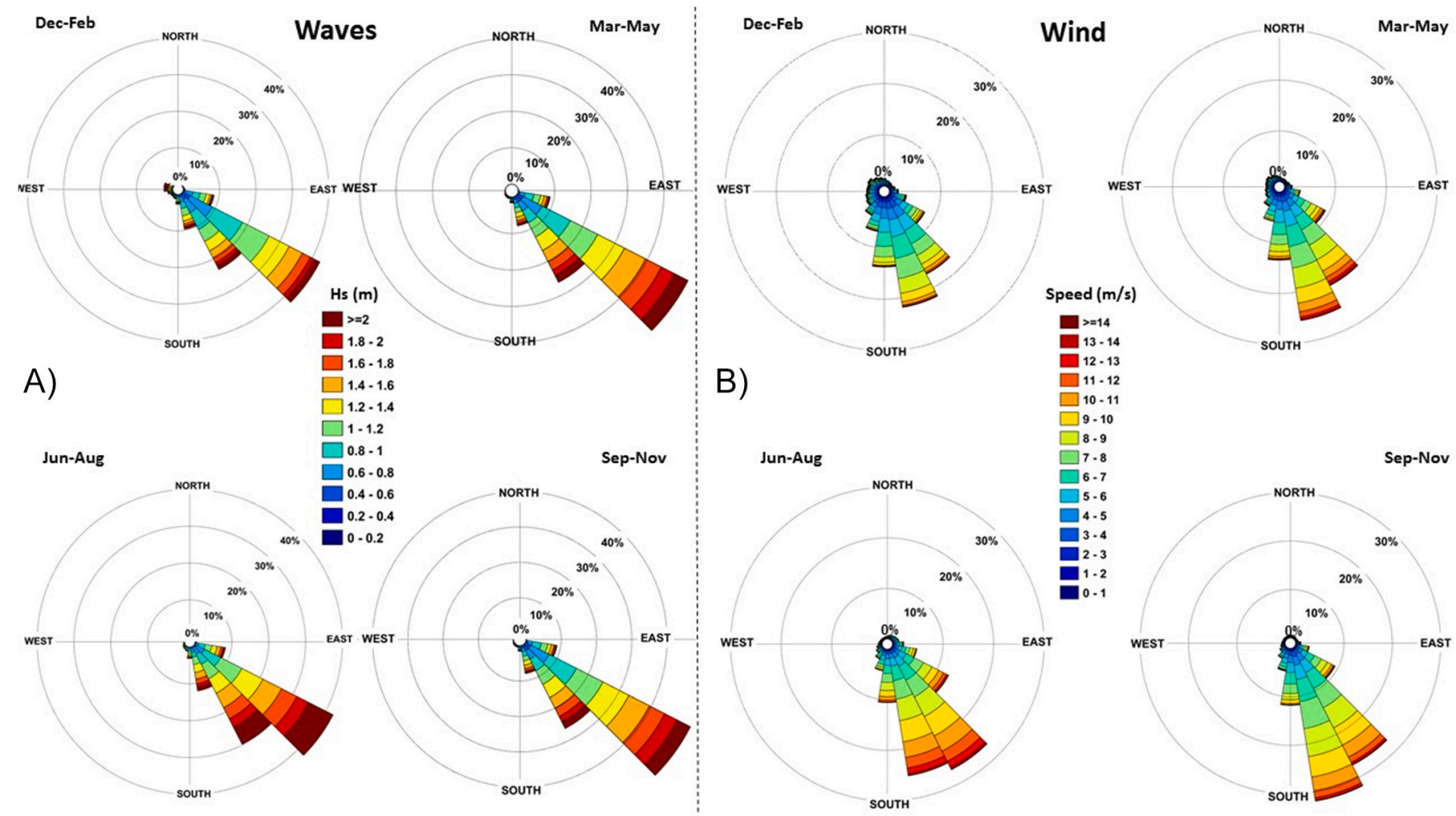

Fig. 3. Wave roses (A) and wind roses (B) per season for Port Vila, Vanuatu using WW3 data for the period of 1979-2018. 

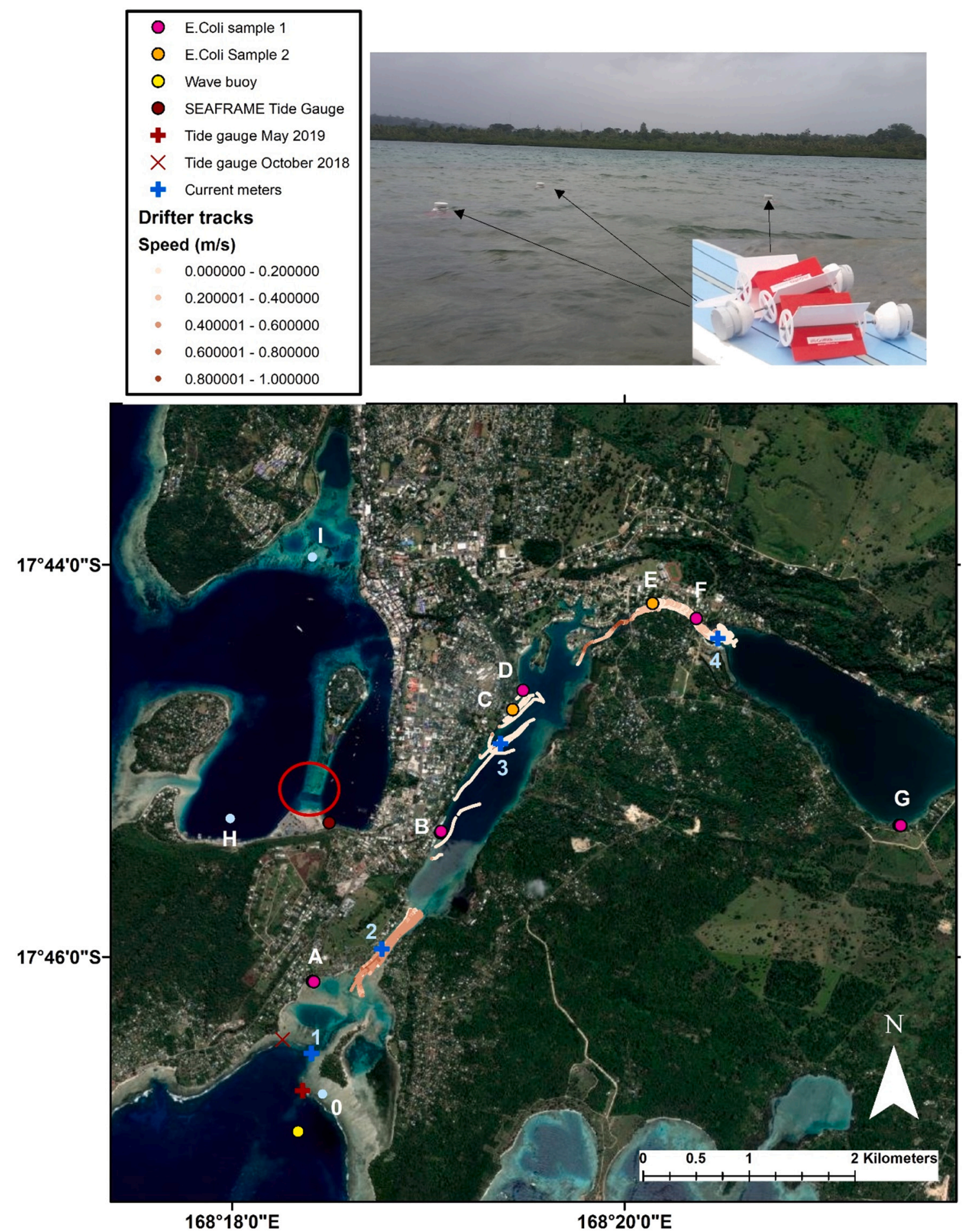

Fig. 4. Location of data collected. Pink and orange dots are the E. coli sample collected in May 2019 and from October 2019 to February 2020 respectively. Blue crosses are the locations of the current meters, red dots and crosses are tide gauges and the yellow dot is the wave buoy spotter. The red circle shows the area that was dredged in 2017. Numbers and letters are results from models presented later in the paper. The lines in the pink shades are the drifters track, darker colours showed higher speed. (For interpretation of the references to colour in this figure legend, the reader is referred to the web version of this article.)

developed in Delft 3D (Fig. 4). The locations were chosen to be able to quantify the speed at the entrance, between lagoons where the speed significantly increase and in Erakor Lagoon 2 where the current is expected to be lower. Current meters 1,2 and 4 were placed to be able to calculate a rate of water system exchange.

LaGrangian drifters were released in different parts of the lagoon (Fig. 4) to inform the circulation by measuring surface current and were used as indicator for calibrating the model. The design of the drifters was inspired by the small drifter from Spencer et al. (2014) using AMOD AGL3080 GPS Data Loggers stored in a PVC container bolted to the top of the frame (Fig. 4). The current at the surface was deduced from the position of drifters released at different parts of the lagoon. The influence of wind on the drifters were reduced by four drag-producing vanes (Fig. 4) attached together to a threaded piece of rod of $0.5 \mathrm{~m}$ which acted together as a drogue for stability and control (Spencer et al., 2014). In addition, windage and inertial force should have negligible effect on the 

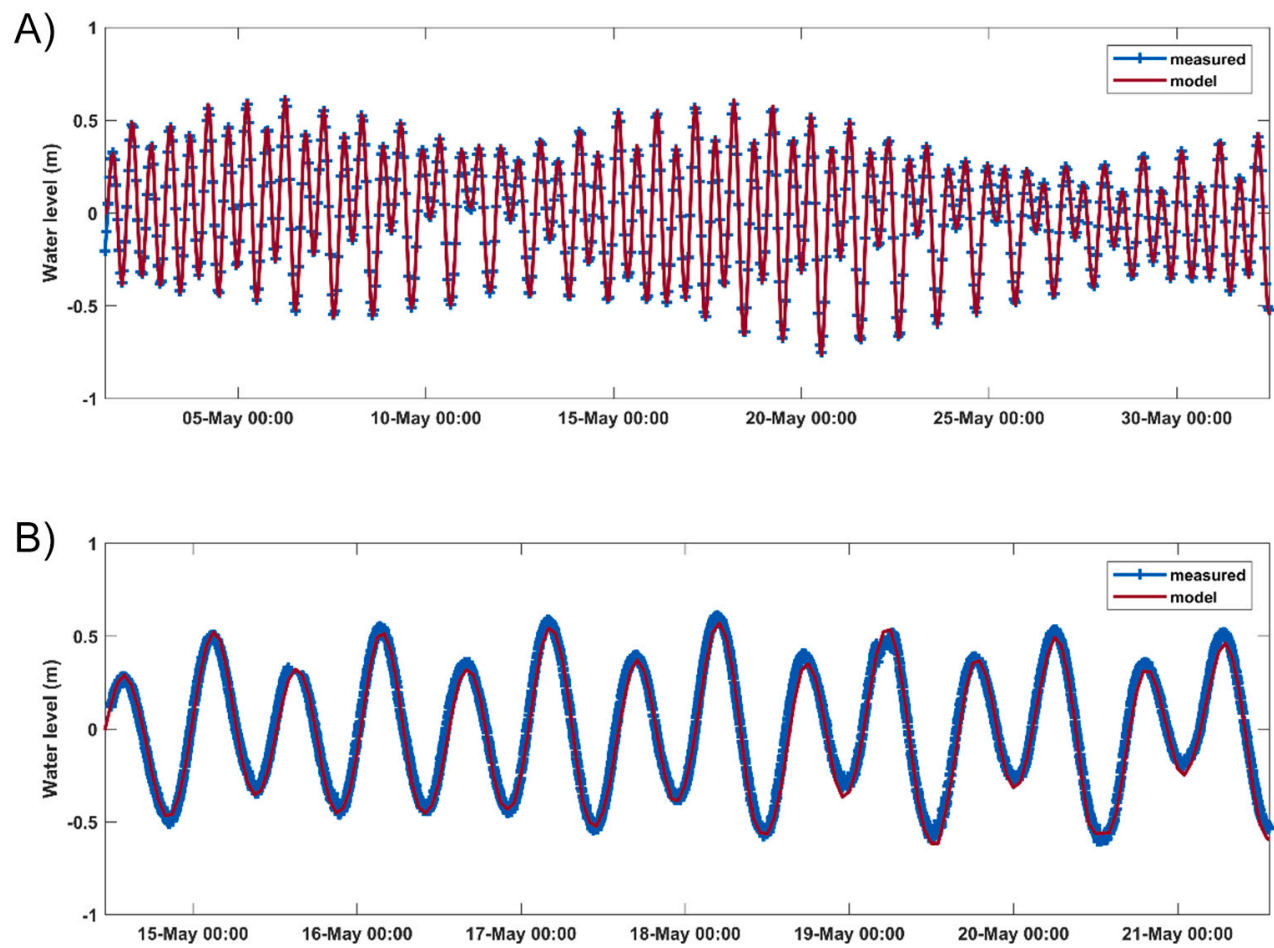

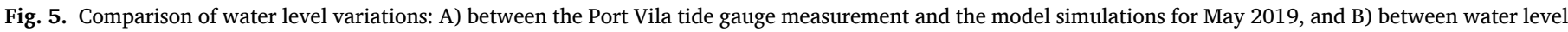
measured with pressure sensor on the reef flat and the model simulation (bottom) using scenario S3.

drifters over time as only a small portion of the drifters are exposed above the surface water (Spencer et al., 2014). Indicative tracks and speed are shown in Fig. 4. The drifters were always deployed during low tide with $30 \mathrm{~min}$ difference interval were travelling from upstream (Erakor 3) to downstream of the lagoon (Erakor 1). This experience was carried out from 18/05/2019 to 22/05/2019 during the spring tide and low tide at 3 main locations in Erakor lagoon system: - at the upstream part of the channel connecting Erakor 3 and Erakor 2, at the upstream part of Erakor 2 around the hospital discharge, and at the upstream part of the channel connecting Erakor 2 and Erakor 1 (Fig. 4). In Erakor 2, sometimes the drifters ended in the shallow waters on border of the lagoon, when this happened, the tracker was stopped and restarted at the same level but in the middle of the lagoon.

\subsubsection{Measurements of E. coli bacteria}

We selected sites for sampling that are used for community activities such as swimming and fishing, and with tourism-based activities. Measurements of $E$. coli Bacteria in surface water has been tested in five key locations (Fig. 4) within Erakor Lagoon in May 2019 using Aquagenx Compartment Bag Tests (CBTS) as shown in Fig. 5 (Aquagenx, 2021). CBTs produce a quantitative estimate of $E$. coli concentration based on a most probable number (MPN) per $100 \mathrm{~mL}$ (Stauber et al., 2014; Gronewold et al., 2017).

The compartment bag test is a self-contained, portable kit providing the ability to detect and quantify the presence of $E$. coli (Stauber et al., 2014) in recreational waters using a 1:10 dilution. These test kits are ideal for on-site testing where laboratory resources are not readily available. Colour changes to a distinctive blue colour within bag compartments of 10,30,56, 3 and $1 \mathrm{~mL}$ volumes to indicate positive results of $E$. coli in the compartment bag test and the concentration of $E$. coli is calculated using the volumes of positive and negative compartments to estimate an MPN/100 mL. Positive results for $E$. coli in the compartments indicates the presence of total coliforms. These coliforms can also be observed separately with UV Flashlight. Additional instructions on interpretation are provided in Aquagenx (2020). Sites were selected and sampled in the first month (May 2019) of the campaign (Fig. 4) including nearshore beach resorts, hospital discharge site and resort discharge sites. Sites were located at the entrance of the lagoon system and Erakor 1 (marked with Points 0 and A in Fig. 4), at the downstream part of Erakor 2 (Point B), at the nearshore beach from the hospital discharge (Point $\mathrm{C}$ ), at the hospital discharge (Point D), in the channel connecting Erakor 3 and 2 (Points E and F) and at the upstream part of Erakor 3 (Point G). The downstream part of Erakor lagoon is Erakor 1 during the ebb tide. Spills have been observed coming from pipes at the hospital site (Point D) and at the downstream part of Erakor 2 (Point B), and sampled during the discharge of water from these pipes. Other sites were sampled from October 2019 to June 2020 on a monthly basis, and again, the sites focused on resort discharge beaches or nearshore amenity areas (community fishing and swimming). Results are shown later in Table 2.

\subsection{Numerical modelling}

\subsubsection{Model set-up}

To understand the circulation in the lagoon systems of Vila Bay and Erakor, a hydrodynamic model assessing the contribution of waves, tide and wind on the flushing time of the system was developed with Delft 3D which solves the Reynolds averaged Navier-Stokes equation (Deltares, 2014). The model was developed in $2 \mathrm{D}$ and used a barotropic flow. The model shown in Fig. 9 consists of two nested grids of progressively increasing resolution (Faivre et al., 2019). The largest wave extends from WW3 point 1 offshore and the resolution of the grids are $150 \mathrm{~m} \times$ $150 \mathrm{~m}$ and $50 \mathrm{~m} \times 50 \mathrm{~m}$ respectively. The flow grid is similar to the smallest wave grid with a resolution of $\sim 50 \mathrm{~m} \times 50 \mathrm{~m}$ and 117,493 elements (Fig. 9). The resolution of the model did not allow to solve in detail the channels in the upper part of the lagoon. However, there were enough grid cells to resolve the rest of the lagoon system.

Four types of forcing were used as shown in Fig. 2, S1: only forced with the tide; S2: forced by tide and wind, S3: forced by waves and tide and S4: forced by tide, waves and wind. The wave model was coupled with the flow by information from the wave module being passed to the flow module followed by calculation of wave-induced residual flow and 
Table 2

Recreational water risks associated with E. coli collected in Erakor Lagoon system given with Most Probable Number (MPN)/100 mL for a guide to the degree of sewage contamination.

\begin{tabular}{|c|c|c|c|c|c|c|c|c|c|}
\hline Date & Weather & \begin{tabular}{|l} 
Entrance \\
Iagoon (1)
\end{tabular} & \begin{tabular}{|l} 
Erakor 1 \\
(Point A)
\end{tabular} & $\begin{array}{l}\text { Downstream } \\
\text { of Erakor } 2 \\
\text { (Point B) }\end{array}$ & $\begin{array}{l}\text { Hospital } \\
\text { discharge } \\
\text { (Point D) }\end{array}$ & \begin{tabular}{|l} 
Adjacent \\
beach \\
near the \\
hospital \\
discharge \\
(Point C)
\end{tabular} & $\begin{array}{l}\text { Discharge } \\
\text { source in } \\
\text { the } \\
\text { channel } \\
\text { connectin } \\
\text { g Erakor } 3 \\
\text { to Erakor } \\
2 \\
\text { (Point F }\end{array}$ & $\begin{array}{l}\text { Adjacent } \\
\text { beach of a } \\
\text { discharge } \\
\text { source } \\
\text { located in } \\
\text { the } \\
\text { channel } \\
\text { connectin } \\
\text { g Erakor } 3 \\
\text { to Erakor } \\
2 \\
\text { (Point E) }\end{array}$ & $\begin{array}{l}\text { Upstream } \\
\text { of Erakor } \\
3 \\
\text { (Point G) }\end{array}$ \\
\hline \begin{tabular}{|l|}
$19 / 05 / 2019$ \\
High tide \\
\end{tabular} & Sunny & & $>1000$ & 136 & $>1000$ & & & & \\
\hline $\begin{array}{l}19 / 05 / 2019 \\
\text { Low tide }\end{array}$ & Sunny & & - & $\begin{array}{l}47^{*} \\
P 100\end{array}$ & $\begin{array}{l}>1000^{*} \\
>1000^{* *}\end{array}$ & & 483 & & \\
\hline \begin{tabular}{|l|}
$20 / 05 / 2019$ \\
Low tEnide
\end{tabular} & Sunny & & 0 & 47 & $>1000$ & & & & \\
\hline \begin{tabular}{|l|}
$28 / 05 / 2019$ \\
Low tide
\end{tabular} & Sunny & & 12 & $>1000$ & 24 & & $>1000$ & & 39 \\
\hline $\begin{array}{l}28 / 05 / 2019 \\
\text { high tide }\end{array}$ & Sunny & & 136 & 84 & 96 & & 21 & & 136 \\
\hline $\begin{array}{l}03 / 06 / 2019 \\
\text { low tide }\end{array}$ & cloudy & 26 & & & & & & & \\
\hline \begin{tabular}{|l|}
$28 / 10 / 2019$ \\
Low tide \\
\end{tabular} & $\begin{array}{l}\text { Cloudy/ra } \\
\text { ining }\end{array}$ & - & $>1000$ & $>1000$ & $>1000$ & & - & $>1000$ & $>1000$ \\
\hline $\begin{array}{l}26 / 11 / 2019 \\
\text { Low tide }\end{array}$ & Cloudy & - & 483 & $>1000$ & $>1000$ & & - & 136 & $>1000$ \\
\hline $\begin{array}{l}07 / 01 / 2019 \\
\text { Low tide }\end{array}$ & Sunny & - & 483 & 483 & & 483 & - & 483 & $>1000$ \\
\hline $\begin{array}{l}24 / 01 / 2020 \\
\text { Low tide }\end{array}$ & $\begin{array}{l}\text { Raining/ } \\
\text { Cloudy }\end{array}$ & - & 136 & $>1000$ & & 483 & - & 96 & 136 \\
\hline $\begin{array}{l}10 / 02 / 2020 \\
\text { high tide }\end{array}$ & $\begin{array}{l}\text { Raining } \\
\text { (cyclone } \\
\text { offshore) } \\
\text { Wind } \\
\sim 28 \mathrm{~km} / \mathrm{h} \\
\end{array}$ & - & $>1000$ & $>1000$ & & $>1000$ & - & $>1000$ & $>1000$ \\
\hline $\begin{array}{l}10 / 02 / 2020 \\
\text { Low tide }\end{array}$ & $\begin{array}{l}\text { Raining } \\
\text { (cyclone } \\
\text { offshore) }\end{array}$ & - & $>1000$ & $>1000$ & & $>1000$ & - & 483 & 326 \\
\hline $\begin{array}{l}11 / 03 / 2020 \\
\text { Low tide }\end{array}$ & $\begin{array}{l}\text { Sunny } \\
\text { Wind } \\
\sim 18 \mathrm{~km} / \mathrm{h} \\
\end{array}$ & & 136 & 483 & & 483 & & 136 & 136 \\
\hline $\begin{array}{l}\text { 09/04/2020 } \\
\text { Low tide }\end{array}$ & $\begin{array}{l}\text { Sunny/cl } \\
\text { oudy } \\
\text { Wind } \\
\sim 21 \mathrm{~km} / \mathrm{h}\end{array}$ & & 136 & 136 & & 483 & & 136 & 483 \\
\hline $\begin{array}{l}\text { 09/05/2020 } \\
\text { Low tide }\end{array}$ & $\begin{array}{l}\text { Sunny } \\
\text { (rain } \\
\text { previous } \\
\text { days) } \\
\text { Wind } \\
\text { around } \\
8 \mathrm{~km} / \mathrm{h} \\
\end{array}$ & & 136 & 483 & & 483 & & 483 & 136 \\
\hline $\begin{array}{l}\text { 06/06/2020 } \\
\text { Low tide }\end{array}$ & $\begin{array}{l}\text { Raining } \\
\text { Wind } \\
\text { around } \\
30 \mathrm{~km} / \mathrm{k} \\
\end{array}$ & & 136 & & & $>1000$ & & & \\
\hline
\end{tabular}

\begin{tabular}{|l|l|l|l|l|l|l|l|}
\hline Hazard & $\begin{array}{l}\text { Low } \\
\text { risk } \\
\text { Safe }\end{array}$ & $\begin{array}{l}\text { Low risk } \\
\text { Probably safe }\end{array}$ & $\begin{array}{l}\text { Low risk } \\
\text { Possibly } \\
\text { safe }\end{array}$ & $\begin{array}{l}\text { Intermediate risk } \\
\text { Possibly safe }\end{array}$ & $\begin{array}{l}\text { High risk } \\
\text { Probably } \\
\text { unsafe }\end{array}$ & $\begin{array}{l}\text { Very high risk } \\
\text { Unsafe }\end{array}$ & Very unsafe \\
\hline MPN/100 mL & 0 & $10-40$ & $47-84$ & $91-96$ & $136-171$ & $326-483$ & $>1000$ \\
\hline $\begin{array}{l}\text { Upper 95\% } \\
\text { Confidence } \\
\text { Level/100mL }\end{array}$ & $0-28.7$ & $51.40-109.4$ & $227.5-211.9$ & $370.40-376.8$ & $\begin{array}{l}830.60- \\
563.5\end{array}$ & $1455.5-3519.1$ & 94351 \\
\hline
\end{tabular}

*Beach.

$*$ * Discharge.

Stokes drift. The model used to estimate the effect of the dredge on the circulation in Vila used the same wave model as the previous model for the coarser grid and two other waves nested grids of $75 \mathrm{~m} \times 75 \mathrm{~m}$ and $37 \mathrm{~m} \times 37 \mathrm{~m}$ and one more nested grid for the flow model with a resolution of $\sim 10 \mathrm{~m}$ by $10 \mathrm{~m}$ (Fig. 2). The bathymetry and topography were based on LIDAR data and a Digital Elevation Model (DEM) generated by the UK Hydrographic Office at a spatial resolution of $5 \mathrm{~m}$ covering bathymetry down to $50 \mathrm{~m}$ depth, courtesy of the Vanuatu 


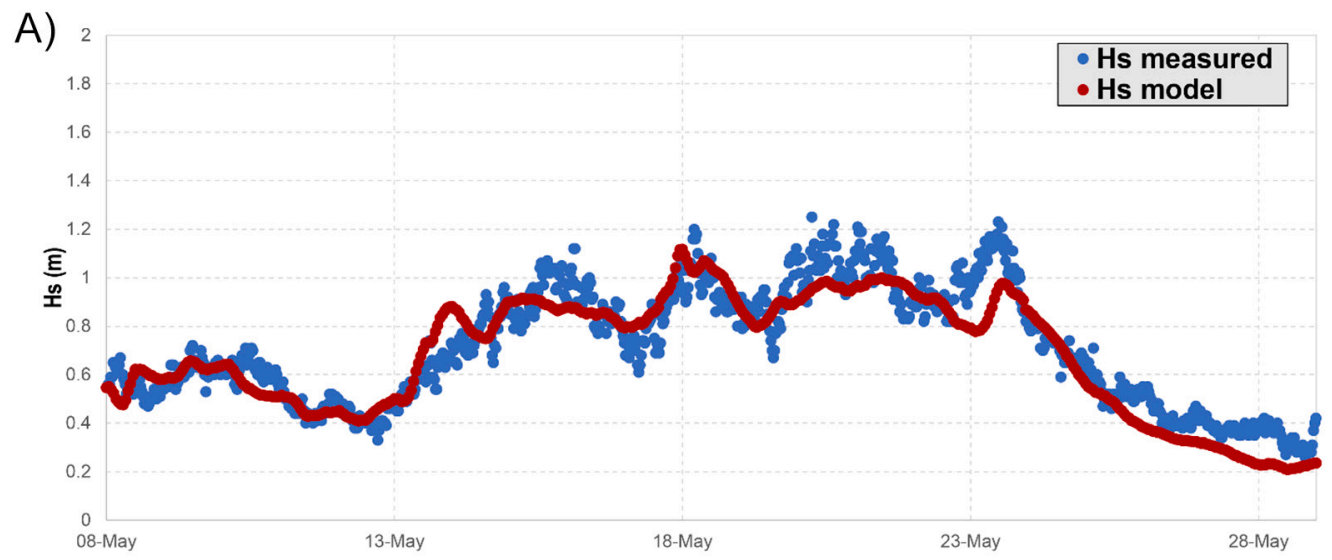

B)

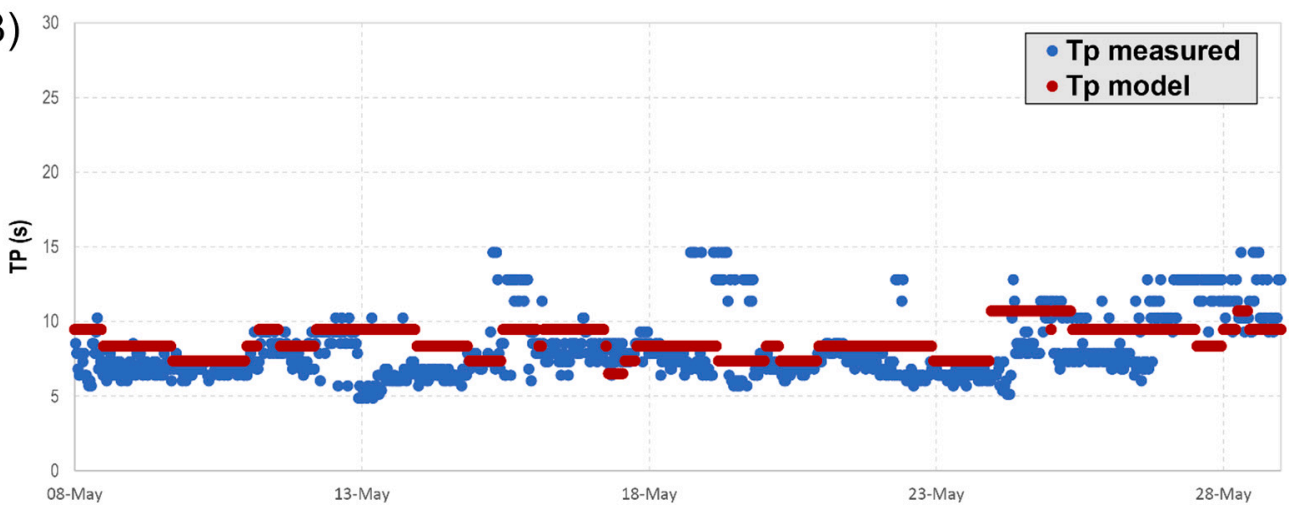

Fig. 6. Comparison between measured and model data for: A) the significant wave height, and B) the relative wave peak period.

A)

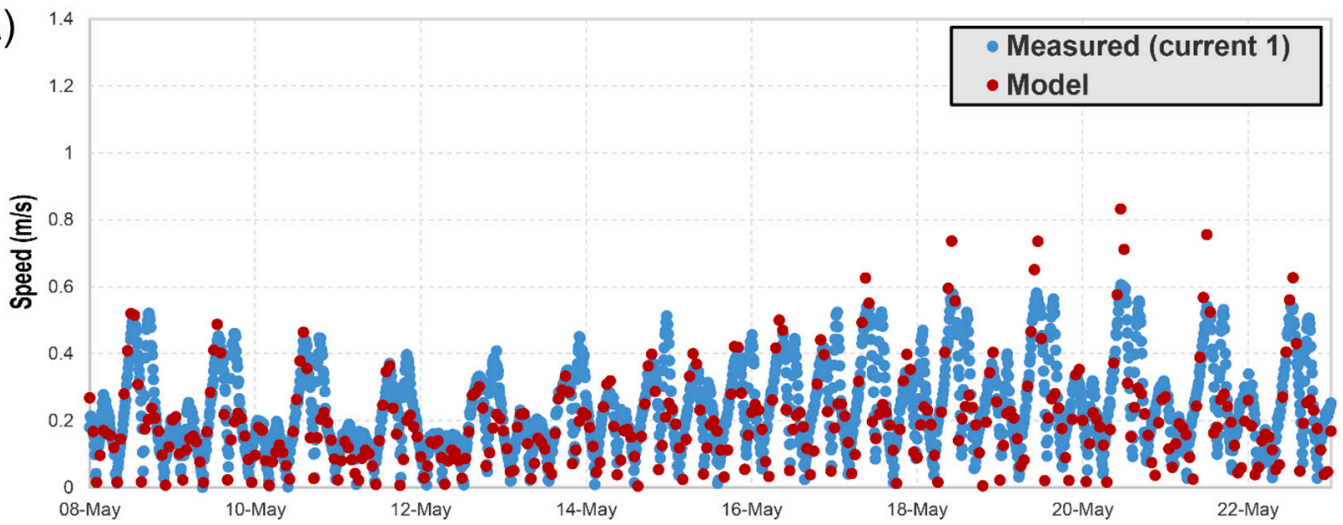

B)

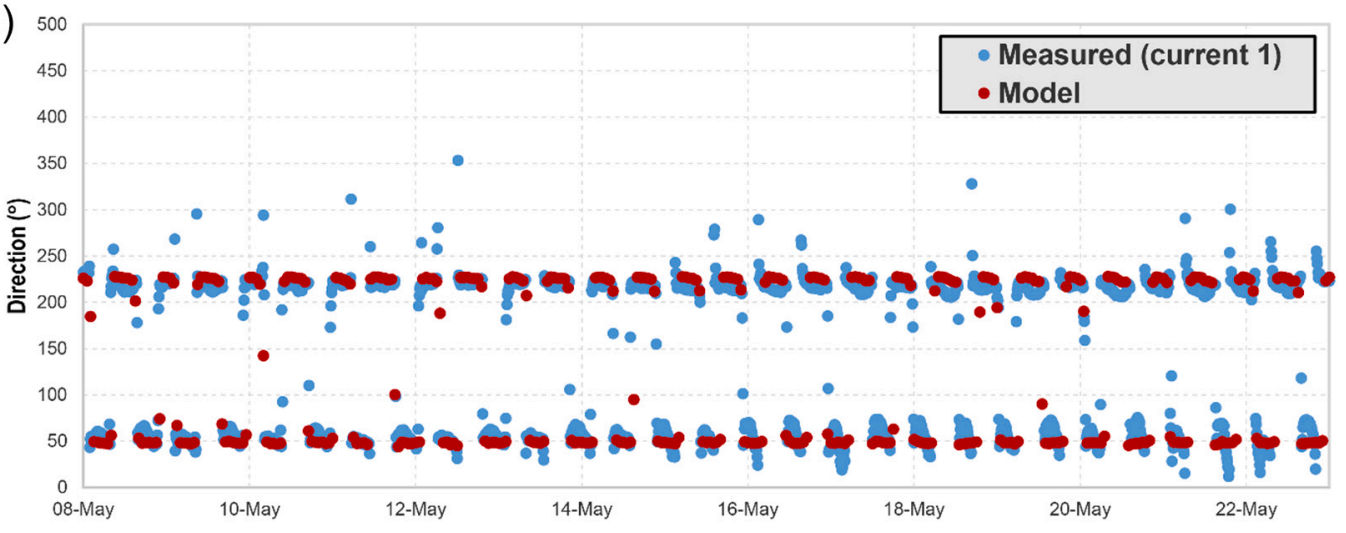

Fig. 7. Comparison between modelled and observed current speed A), and direction in nautical B) at the entrance of the lagoon. 0 degree represents North direction. 

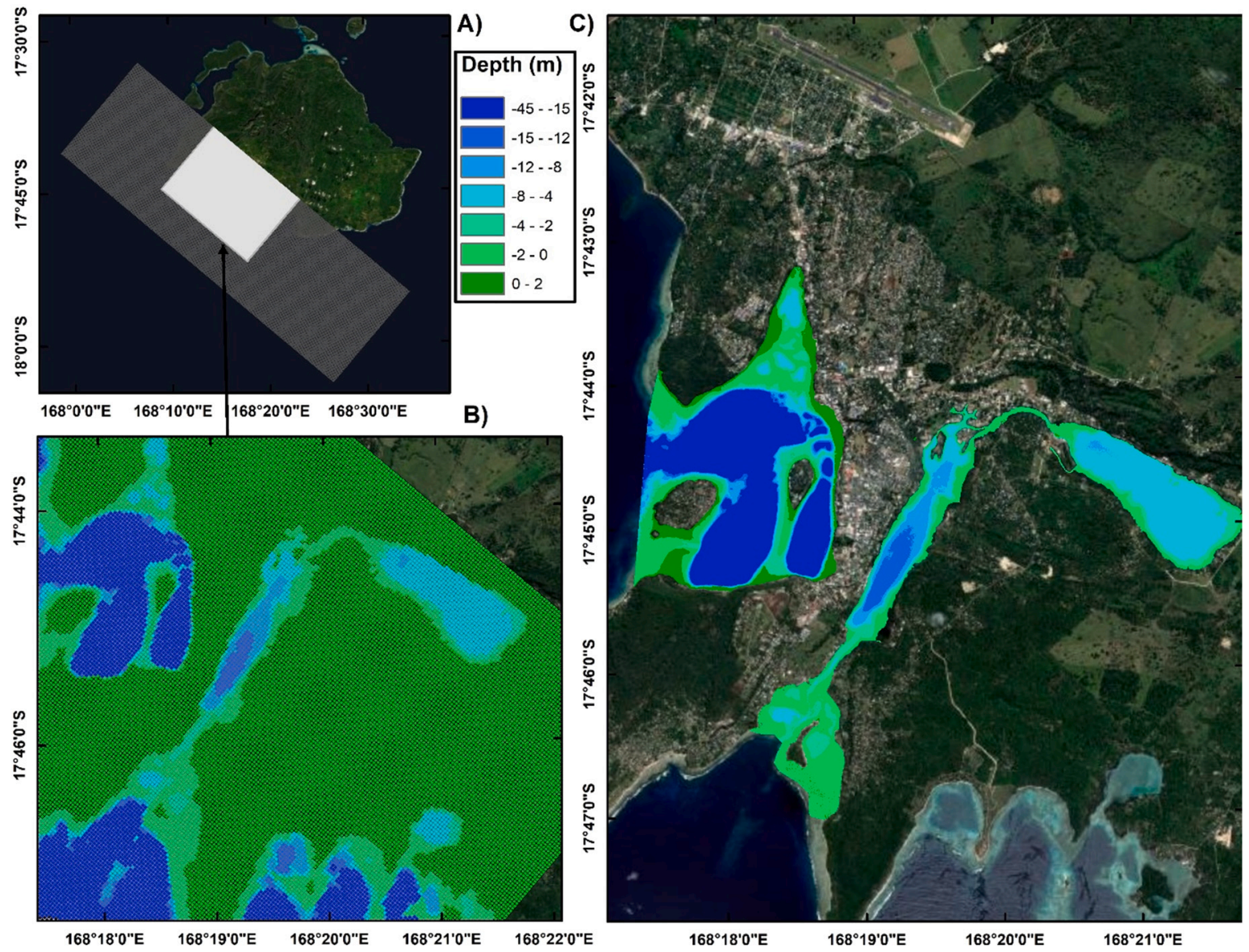

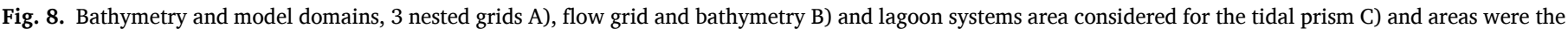
tracers were set initially to " 1 ".

government. Data for other sections of the bathymetry were sourced from GEBCO's gridded bathymetric dataset (GEBCO Compilation Group, 2020). The Shepard weighted averaging method was used to define a depth value for each grid cell. Triangular interpolation was applied between adjacent survey lines (Fig. 9). The NOAA WW3 wave data at Point 1 (Lon: 168.16681; Lat: -17.833269) was used as a wave input to force the model at the offshore boundaries. The wave characteristics used for the model are the significant wave height (Hs), the wave peak period (Tp) and the wave direction (Dir). The model was calibrated over the period of the 4/10/2018 to the 09/10/2018 with water levels and wave data collected by this study at the entrance of Erakor Lagoon and over the month of May using the wave buoy shown in Fig. 4.

To analyse the pollution in the lagoon a passive tracer was implemented in Erakor Lagoon system and Vila Harbor into the flow module. The concentration of the passive tracer follows an advection-diffusion equation. The value of this tracer was set initially to " 1 " in the lagoon system and to " 0 " outside the system, with " 0 " indicating the absence of the pollutant. The concentration of the tracer could be set as the properties of pollutants for further investigations.

We defined the lagoon flushing time as the time required for the passive tracer to disappear from the system which was determined as being equal to the time for the concentration of a tracer to fall to within 1/e (0.37) of its original value (Brodie et al., 2012; Wang et al., 2007). This time was then adopted as equating with the residence time. The renewal time for the entire lagoon system was then calculated.

\subsubsection{Validation of the model}

- Water levels
The model was calibrated with the Port Vila tide gauge located in Vila Bay Harbor (Fig. 1) for the month of May 2019.

The model reproduced sufficiently well the phase and amplitude during the tidal cycle of May 2019 with a root mean square error, RMSE of $0.012 \mathrm{~m}$ at the SEAFRAME tide gauge in Vila Bay and $0.047 \mathrm{~m}$ inside the lagoon be considered fit-for-purpose (Fig. 6). Note that the mean bias is negligible and that variation in water level through the lagoon is due to the gradient created by the outer reef

\section{- Wave buoy}

The model was calibrated with the wave buoy installed in May 2019 outside the reef (Fig. 7). The model demonstrated sufficiently good agreement with a RMSE of $0.10 \mathrm{~m}$ for the wave height and of $2.5 \mathrm{~s}$ for the wave peak period at the wave buoy location to be considered fit-forpurpose.

\section{- Current with the Marotte}

The model was calibrated with current meters and was also considered fit-fort purpose (Fig. 8). During the spring tide on the 19th of May, the model overestimates the speed at the current meter 1 position during the ebb tide. This is likely due to the coarseness of the model and local winds. While the model was forced with uniform wind from the airport station, the direction is well represented.

Delft 3D model was applied here with a dispersion coefficient of 0.1 $\mathrm{m}^{2} / \mathrm{s}$. In order to calculate the dispersion characteristics of the drifters, the following equation was used (Spencer et al., 2014). 


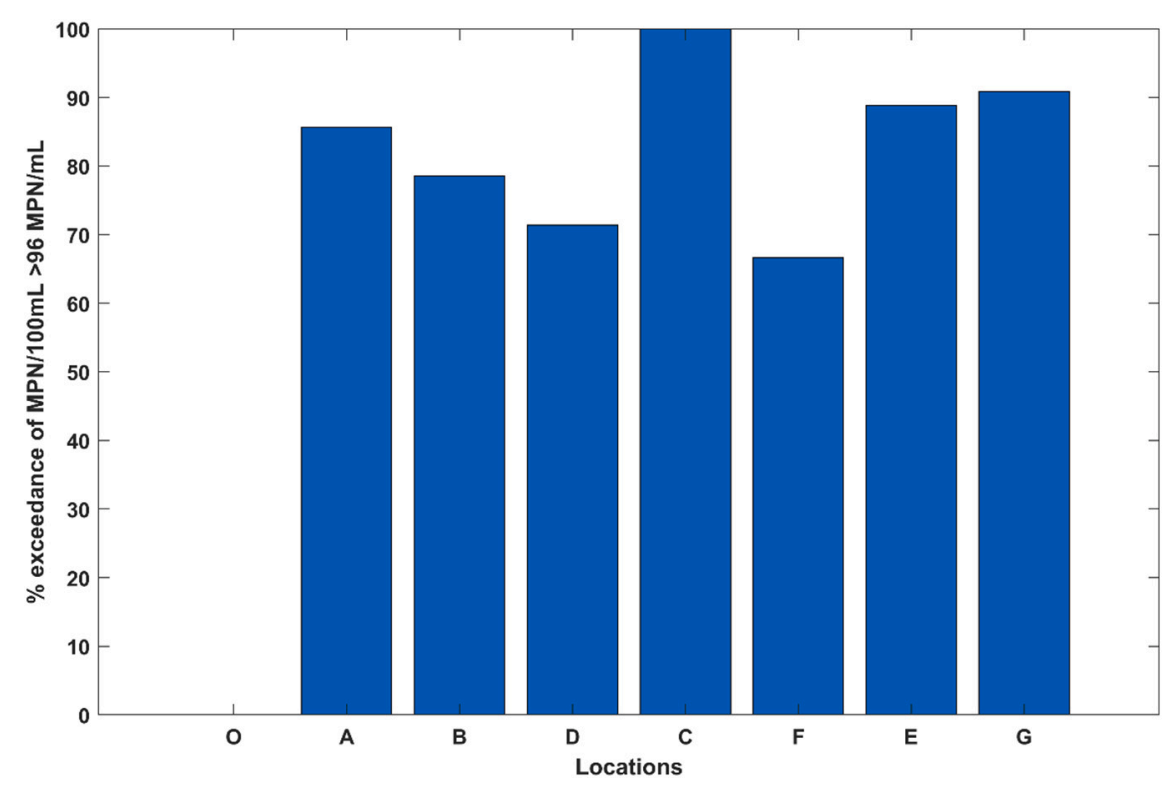

Fig. 9. Exceedance expressed as a percentage of $E$. coli as assessed against U.S. EPA Recreational Water Criteria Recommendation1 (Aquagenx) per location. Thresholds for $E$. coli are set against the U.S. EPA Recreational Water Criteria Recommendation1. The percentage exceedances are calculated from the number of data points between May 2019 and June 2020that have exceeded the threshold of Intermediate risk ( $>96 \mathrm{MPN} / 100 \mathrm{ML}$ or $>$ to 376.8/100 ML using the upper 95\% confidence Level/ $100 \mathrm{~mL})$.

$$
K=-\frac{1}{4} \frac{\partial\left(\sigma_{x} \sigma_{y}\right)}{\partial t}
$$

where $\mathrm{K}$ is defined as the dispersion coefficient computed using the longitudinal ( $\mathrm{x}$ ) and latitudinal (y) cluster displacement variance $\sigma_{\mathrm{x}} \sigma_{\mathrm{y}}$ of the drifters with respect to time $t$ (Tseng, 2002).

Additionally, the order of the speed recorded by the drifters was similar to the modelled speed at the places the drifters were released.

\subsection{Tidal prism}

The tidal prism is the volume of water in the lagoon system between mean high tide and mean low tide, or the volume of water leaving the lagoon system at ebb tide (Davis and Fitzgerald, 2004). Determining the tidal prism is important for calculating the residence time of water and also pollutants in a lagoon system. The flushing time derived from the tidal prism is defined by the shortest possible time during the entire water fraction of the lagoon, it is the lower limit (Matso, 2018) The flushing time is defined as the time interval in which the total amount of the existing lagoon water will be replaced by the new water entering the lagoon system (Guo et al., 2000), and was calculated mathematically as:

$T_{F}=\frac{V_{L}}{Q_{L}} \mathrm{~T}$

where $T_{F}$ is the flushing time; $V_{L}$ is the volume of the lagoon system at the high-water level; $\mathrm{Q}_{\mathrm{L}}$ is the volume of the mixed lagoon water that leaves the lagoon system in the ebb tide; and $\mathrm{T}$ is the duration of the dominant tidal period. In well-mixed estuaries flushing time is often calculated with the mean tidal volume of the estuary and the mean volume of the tidal prism. The volume of the lagoon was calculated using the Lidar data and the surface volume tool in ArcGIS to provide a better understanding of the water exchange during flood tide and ebb tide. The surface volume was calculated during the average conditions of high and low tide and during spring tides conditions. We assumed that the lagoon is well-mixed given its dimensions. Fig. 10 shows the area considering for the tidal prism calculation in Erakor Lagoon system and Vila Bay. The same area was used for the passive tracer.

However as tidal currents are oscillatory, some of the water removed on one ebb tide is always returned on the next flood tide, the water never completely flushes out. As a result, practitioners use an exponential decay function to come up with a final estimate of flushing as introduced earlier by using a passive tracer. The system flushed out when $37 \%$ of the introduced substance remains in the system (Li, 2010) and 63\% has exited the system.

\section{Results}

\subsection{E. coli and faecal contamination}

The health risks for water-based recreational activities of $E$. coli concentration levels are based on seven risk categories from "low" to "very unsafe" assessed against U.S. EPA Recreational Water Criteria Recommendation 1 (Aquagenx, 2021). US EPA guidelines are used across the US to assess water quality and potential impact. For the Erakor Lagoon System and Villa Bay, the results ranged from "low risk" to "very unsafe with predominance of high risk to very unsafe (Table 2).

Over the period of May 2019 to June 2020, 69 samples were collected in different locations of the lagoon (Fig. 4). Samples were first collected close to discharge sources (point D and Point F) and then to the adjacent beaches to see potential impacts. Only 11 samples out of 69 samples collected were considered low risk for recreational water activities defined by $E$. coli inferior to $84 \mathrm{MPN} / 100 \mathrm{~mL}$ while 27 samples out of 69 were considered as very unsafe with $E$. coli superior to 1000MPN/100 mL (Table 2). A total of 55 samples were considered high risk with $E$. coli superior to $136 \mathrm{MPN} / 100 \mathrm{~mL}$ which represents $78 \%$ of the samples collected. Overall, a high level of $E$. coli was identified in the coastal areas of Erakor Lagoon. These results suggest that the lagoon entrance where there is increased exchange with the ocean water, is less contaminated (Table 2). However, only one sample was collected at the entrance in June 2019. Additional samples would allow verification of this observation. Most of the samples were collected at low tide, as it was expected to measure higher $E$. coli. However, the results do not verify completely this assumption in all locations. For example, on the 28th of May 2019, samples were collected at both high and low tide. At that time, only Point B and Point F have higher values during low tide than during high tide. The quality of the water was shown to have worsened over the course of the year. Only one sample out of 47 samples considered as possibly safe. The results also show that the main sources of pollution are likely coming from point sources associated with the hospital and buildings bordering the lagoon or from runoff after heavy rains. Every sample taken directly from discharge points were considered very unsafe with values superior to $1000 \mathrm{MPN} / 100 \mathrm{~mL}$. This suggests that there is poor or no treatment at discharges points.

Fig. 9 presents the exceedances of E. coli for each location within 
Table 3

Surface and volume of Erakor Lagoon system and Port Vila Harbor.

\begin{tabular}{lll}
\hline Study area & Area 2D $\left(\mathrm{m}^{2}\right)$ & Volume $\left(\mathrm{m}^{3}\right)$ \\
\hline Erakor Lagoon system (msl) & $4,596,274.3$ & $20,555,418.9$ \\
Erakor Lagoon system (Low tide) & $3,932,864$ & $17,058,840.7$ \\
Erakor Lagoon system (High Tide) & $4,607,940.5$ & $23,805,335.5$ \\
Vila Harbor (msl) & $5,676,748$ & $99,369,246.2$ \\
Vila Harbor (low tide) & $5,247,550.1$ & $94,966,053.7$ \\
Vila Harbor (high tide) & $5,780,271.3$ & $103,409,747.6$ \\
\hline
\end{tabular}

Erakor lagoon system. Counts of exceedance are shown for MPN/100 mL superior to $96 \mathrm{MPN} / 100 \mathrm{~mL}$ which indicate high risk to very unsafe levels for human health against the U.S EPA Recreational Water Criteria Recommendation 1 (Aquagenx, 2021). All the location at the exception of the entrance (Point $\mathrm{O}$ ) show exceedance of intermediate risk in most of the cases $(>65 \%)$. The adjacent beach to the hospital discharge (Point C) has $100 \%$ exceedance of intermediate risk for health for all the sample collected.

\subsection{Residence time}

By using, the tidal range with the mean high tides and mean low tides 2019 from Port Vila Tide Gauge, we found a range of $1.2 \mathrm{~m}$ and a tidal prism of $6.75 \times 10^{6} \mathrm{~m}^{3}$ for Erakor lagoon and $8.44 \times 10^{6} \mathrm{~m}^{3}$ for Vila Bay.

Table 3 shows the surface and volume of Erakor Lagoon system and Vila Harbor using the tidal range from SEAFRAME tide gauge.

The average tidal range of the SEAFRAME tide gauge at the spring tide is around $1.2 \mathrm{~m}$ and around $0.4 \mathrm{~m}$ at the neap tide. The average

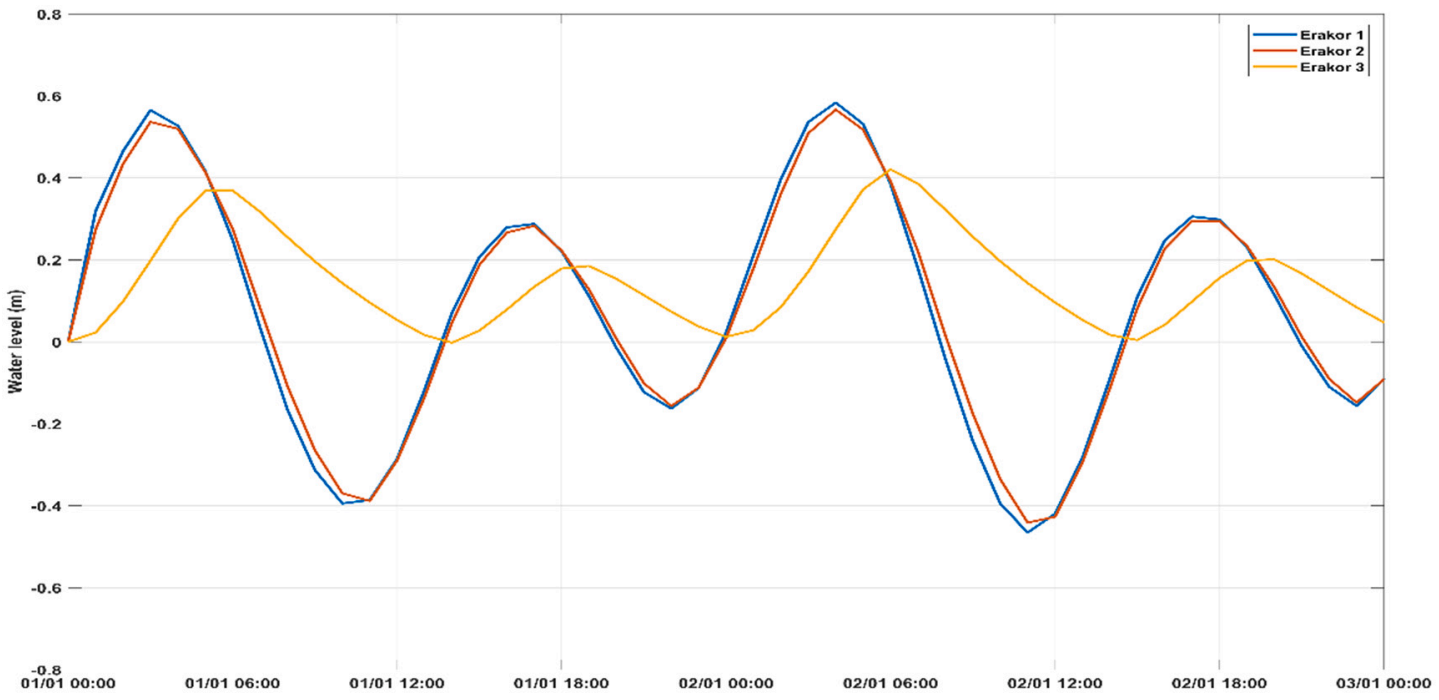

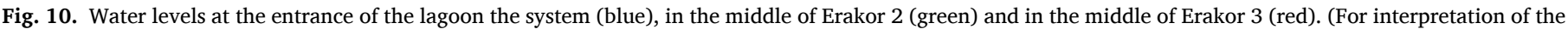
references to colour in this figure legend, the reader is referred to the web version of this article.)

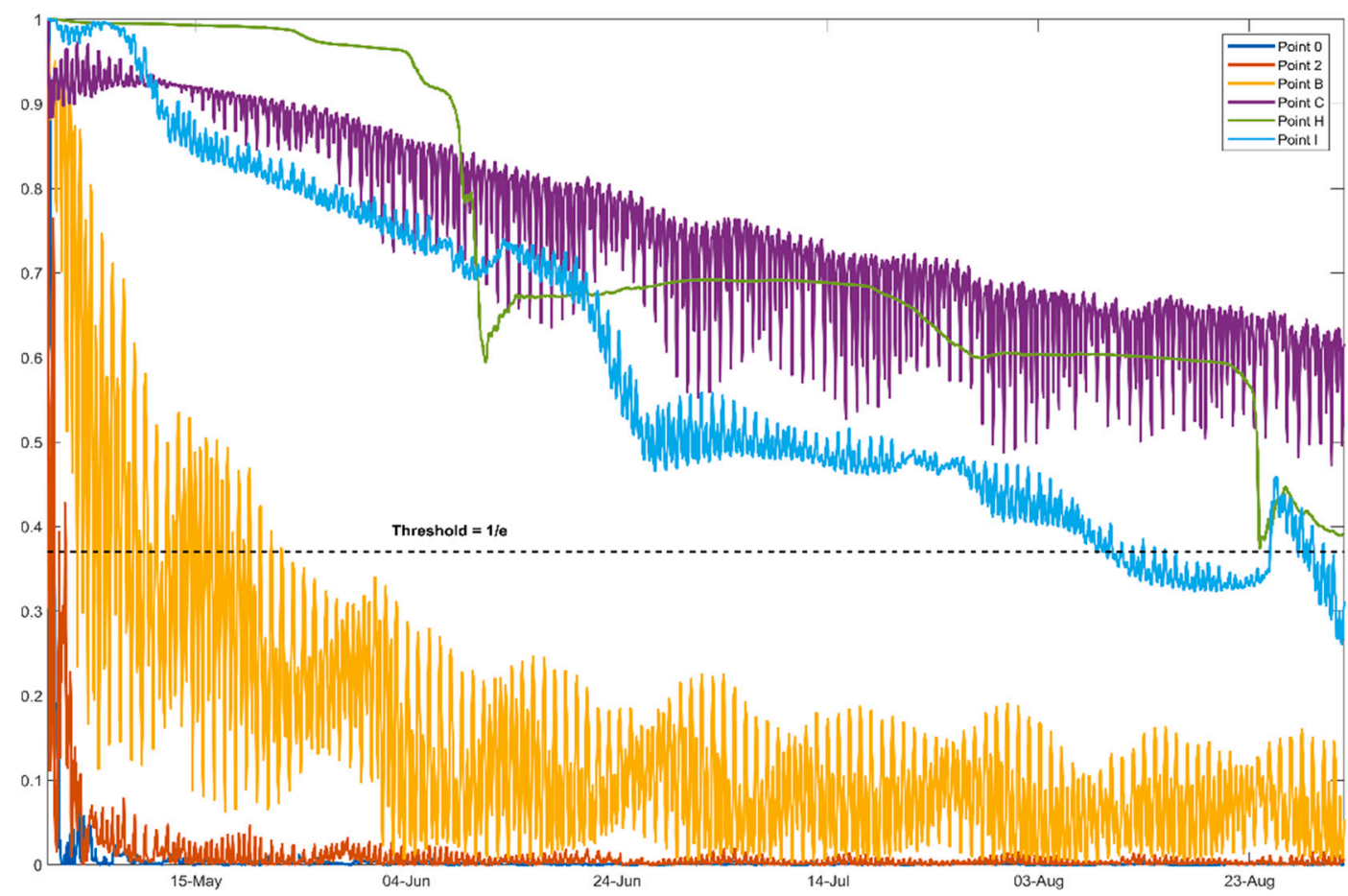

Fig. 11. Concentration of the passive tracer for the coupled wave-flow model. 

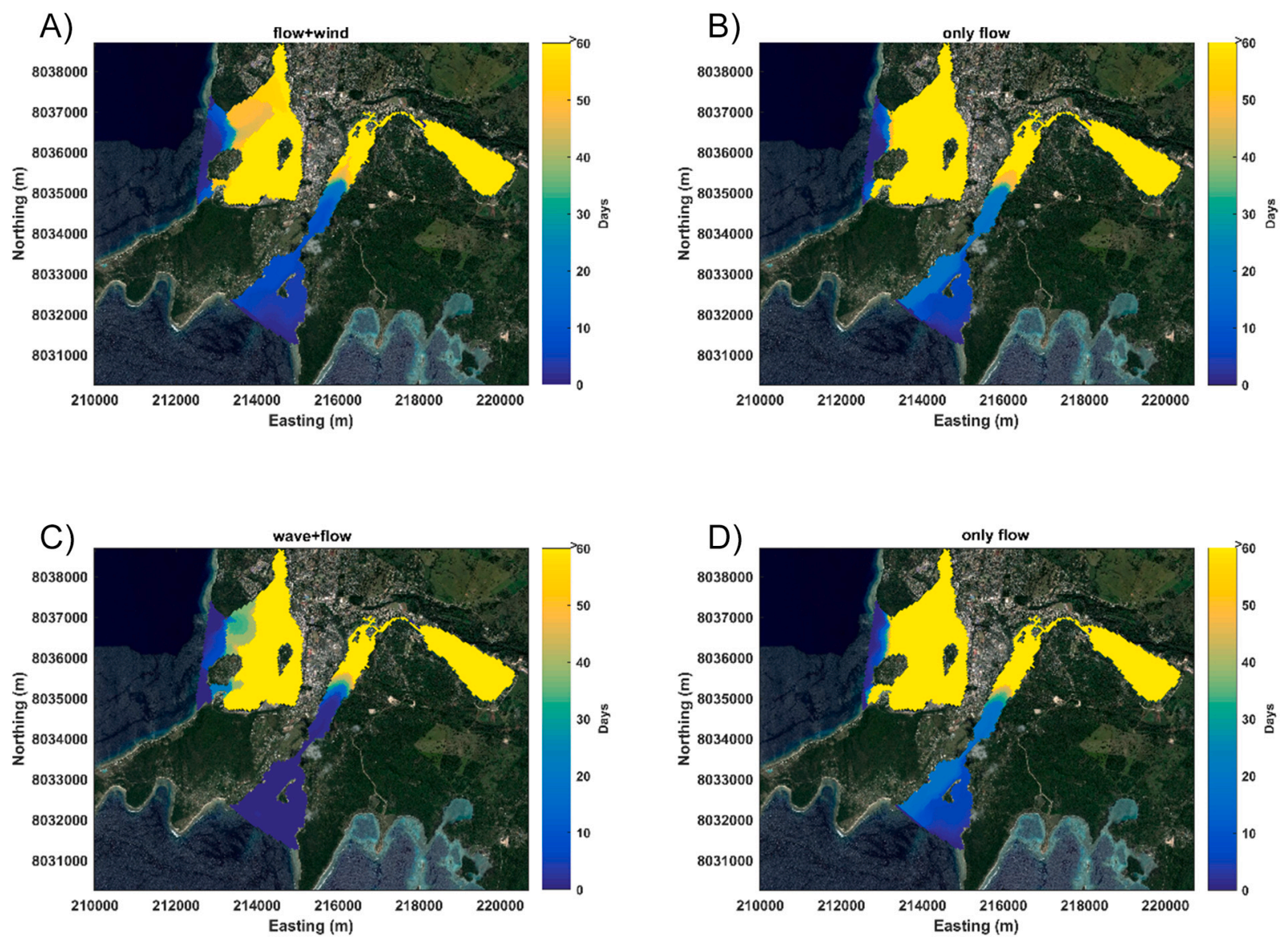

Fig. 12. Lagoon residence times when the model is forced by tide and wind (A), without wind (B), coupled waves and flow (C) and only the tide (D).

range of the tide is around $0.73 \mathrm{~m}$ at the entrance of the lagoon system while the average range of the tide is $0.4 \mathrm{~m}$ in Erakor 3 using the numerical model (Fig. 10). The average surface elevation from the model induced by the flood tide and by the ebb tide are shown in Fig. 11. The furthest from the ocean entrance, the less tidal range amplitude is found. Results from the model showed that the tidal range in Erakor 3 could be $30 \%$ smaller than the entrance. The phase difference found between the lagoon and difference in amplitude has an impact in the flushing time of the lagoon system. A phase difference between Erakor 1 and Erakor 3 was observed with up to $3 \mathrm{~h}$ difference in the phase found between the entrance of the lagoon and Lagoon 2 with the tidal range being smaller in the upstream lagoon. The average surface elevation from the model induced by the flood tide and by the ebb tide are shown in Fig. 10.

The model results showed that the velocity is not uniform at the entrance of the lagoon and the tidal range varies within Erakor lagoon system as the flushing time calculated with the tidal prism calculation would be really approximated. The method using a passive tracer with a numerical model seemed more appropriate than the tidal prism to calculate the flushing time of the lagoon. We continued the study using a conservative tracer as described in the method section to calculate the flushing time of the lagoon systems.

The residence time in Erakor Lagoon system and in Vila Bay was found to be around one year for the former and seven months for the latter using tide data from 2019. A harmonical tidal cycle (29 days) therefore does not enable flushing of all the lagoon system. The entrance of the lagoon has a flushing time on the order of 15 days when only the tide is considered, eight days when the wind is included and $20 \mathrm{~h}$ when the waves are included (Point 0, Fig. 12).

Erakor 1 is flushed at a higher rate than Erakor 2. Residence time in Erakor2 can be described by two trends. First, south of Point B is flushed in approximatively one day. This is the case for Point 2 and the section from Point B to the Hospital (Point C) over 20 days. Second, Erakor 3 flushing time is more than two months long. Furthermore, the full lagoon has a high residence time equivalent to one year. Erakor 2 and Erakor 3 Lagoons have the same geometry, but the former is influenced by wave conditions and tidal conditions while the latter has less tidal and wave influence due to its distance from the ocean.

A comparison between residence times based on varying wind and wave forcing is illustrated in Fig. 13. The entrance of Erakor is flushed in less than a week and wind slightly decreases the flushing time. However, for Lagoon 2, the upstream part of the lagoon system is poorly flushed and has a residence time longer than two months. This outcome is due to the tidal and wave influence in the downstream part (entrance and Lagoon 1) while only a minor influence is evident in upstream part which is more than two kilometres from the entrance. When waves are included in the model, the residence time decreases, and the downstream part of the lagoon system is flushed in less than two days. The upper part of the lagoon remains poorly flushed with a residence time longer than two months.

Vila Bay Harbor has a long residence time over two month-time and the water exchange with the rest of the Bay is quite poor. The water is trapped within the shoreline and towards Iririki Island (Fig. 1). Waves increase the water exchange with the rest of the bay but not enough to flush the full Bay to $\sim 37 \%$ (1/e) of the initial concentration of the passive tracer in two months. Such a high residence time is likely to affect the water quality within the lagoon system and Vila Bay.

\subsection{Impact of wave on residence time}

The model including the tracer was run with tide alone and then tide coupled with waves. It was found that the waves have an impact at the entrance of Erakor Lagoon up to Point B located at the South part Ocean 

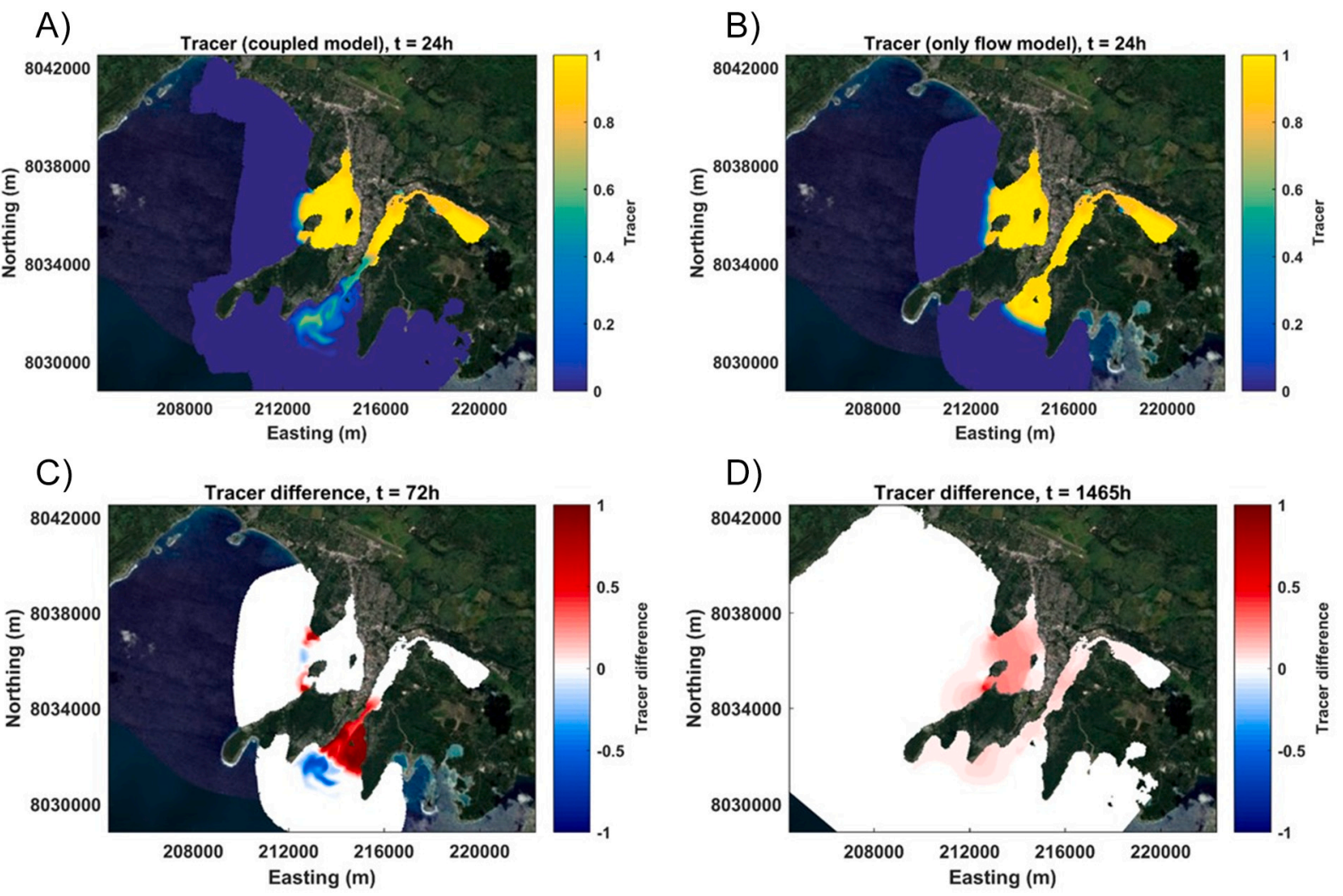

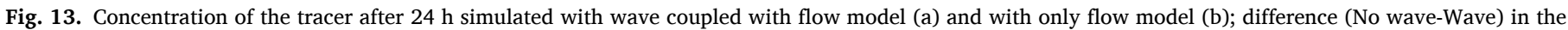
concentration between the two models after 3 days (C) and after 2 months (D).

side of Erakor 2 (Fig. 14) but has less impact on flushing the full lagoon system as the upstream is mainly influenced by the tide. In Vila Harbor, waves are affecting the tracer concentration but over longer (i.e. two month) rather than a few tidal cycles. Fig. 14 shows that after two months of simulations (May-June 2019), the tracer concentration was reduced when waves are included in the model with a difference of up to 0.5 . No differences are observed in the open ocean. It seems that the circulation in Vila Bay Harbor is highly impacted by the wind stress compared to the circulation in Erakor Lagoon system.

Model results showed that waves have a greater influence on flushing in Vila Bay Harbor compared to the lagoon. Results from a two-month simulation (May-June 2019) showed that the concentration with no waves was found to be $20 \%$ more than the model when run with waves. The greatest differences were evident in the first two weeks of the simulation with the effect most apparent at the entrance.

\subsection{Impact of wind in the residence time}

The model showed that concentration of the tracer is likely to be higher during the wet season due to weaker wind than in the dry season, consistent with the findings of Graham et al. (2020). Fig. 15 shows the difference in concentration after one year with and without wind. The model simulation revealed that the lagoon is flushed more quickly when the wind is included than when no wind was considered, and that the tracer concentration after one year is higher when no wind was included in the model than when wind was added. The major difference appears in Vila Harbor where the difference goes up to 0.3. In Erakor Lagoon system, the difference between the model with wind and without wind is not really observed in the downstream of the lagoon but is slightly evident in Erakor 3 which is less influenced by the tide with a difference up to 0.2. In Vila Bay the difference is more apparent with value up to 0.5. Little difference was observed in the deep areas. It seems that the circulation in Vila Bay Harbor is highly impacted by the wind stress compared to the circulation in Erakor Lagoon system.

As the wind was shown to not make a major difference in terms of residence time in Erakor Lagoon, subsequent model analyses were undertaken without considering the wind, resulting in a worst-case study in terms of residence time. All the drifters seemed to be tidally dominated and little influenced by the wind.

\subsection{Climate change and residence time}

The concentration of the tracer was modelled according to projections of sea level rise presented in Table 1 with emissions scenarios and sea level projection of an increase by $0.6-1.1 \mathrm{~m}$ by 2100 with the high emission scenario (Nurse et al., 2014) (Fig. 16).

Model simulations found that projected sea level rise increases the residence time of the passive tracer for the section going from the entrance (Point 0) to the south part of Erakor 2 (Point B) (Fig. 16). At the hospital level (point D), the concentration of the passive tracer is modulated with the tide after a few months, while the concentration of the tracer gets lower with higher sea levels. In the channel linking the two lagoons (point F), sea level rise decreases the concentration of the passive tracer and the same observation is observed in the upper part of the lagoon system in Lagoon 2 (point G). In this part of the lagoon, the concentration of the passive tracer is no longer influenced by the tide.

These results suggest that increasing sea level would decrease the flushing of the lagoon system up to the Hospital discharge and then increase slightly the flushing in the upper part in Lagoon 2. As most of the resorts are located along the first part of the lagoon, the water quality of lagoon system is likely to decrease with rising sea level.

Current speed data were plotted against water levels to establish a link with rising water levels (Fig. 17). When the water level increases, currents slow at the entrance of Erakor Lagoon (current meter 1) and the currents are faster at entrance of Lagoon 2 . These responses would affect the flushing time and the residence time of the full lagoon system is 

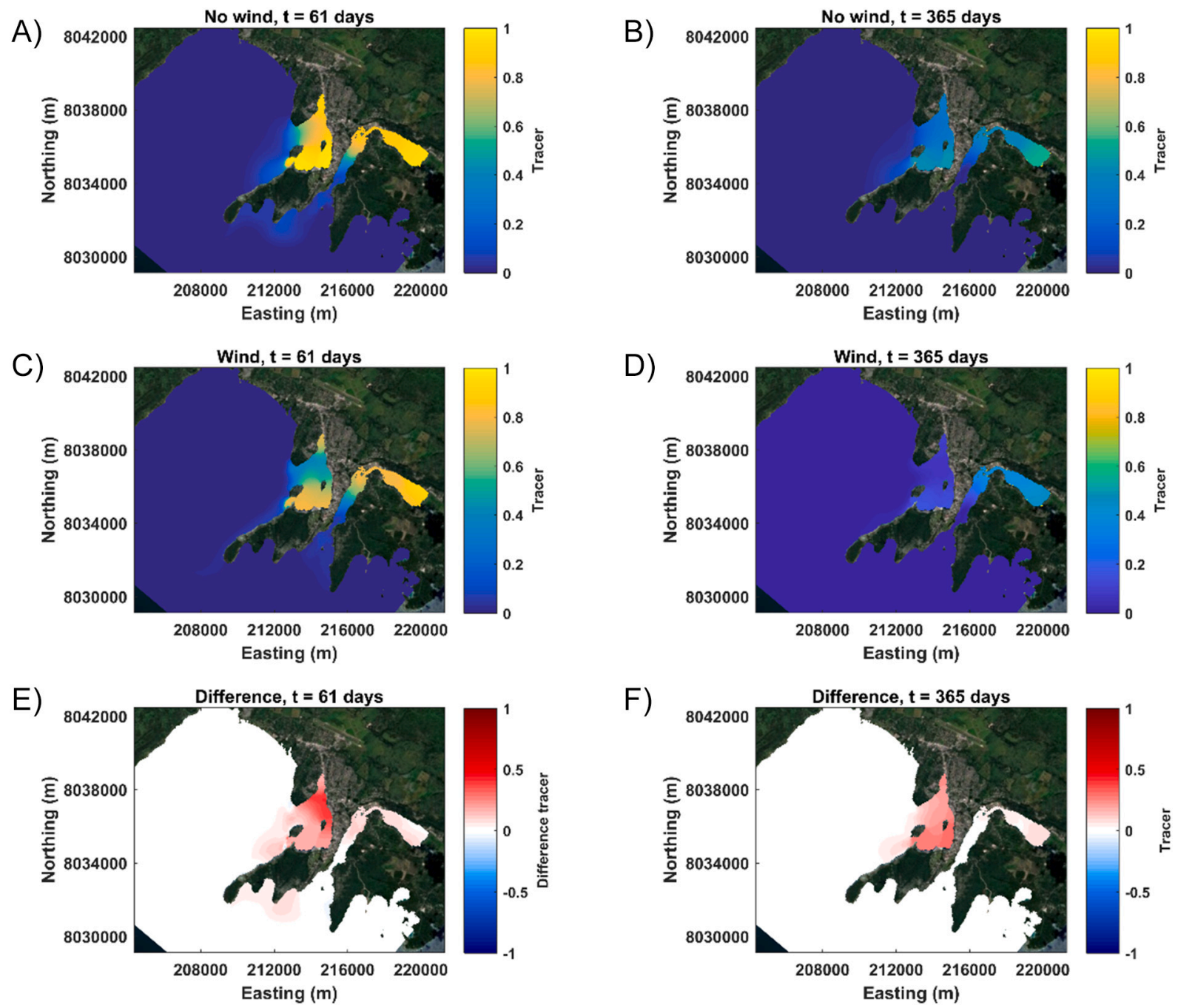

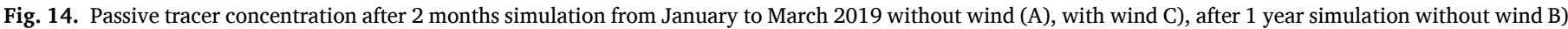

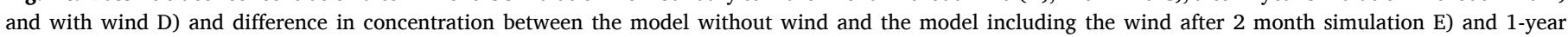
simulation in $2019 \mathrm{~F}$ ).

likely to increase with rising sea levels.

The magnitude of the current is similar on the outgoing and incoming tide at the upstream part of the lagoon (Fig. 18). However, the first part of the lagoon system shows higher current during low tide which explains the flushing at the entrance. Waves are acting on the current direction and play an important role in the flushing time.

\subsection{Dredging impacts on the circulation}

Vila Bay harbor channel was dredged to $5.5 \mathrm{~m}$ depth in 2017 (Fig. 1). The simulation results shown in Fig. 18 investigated the potential impacts of dredging on pollutants concentration. No differences were observed in terms of the residence time in Vila Bay harbor when the model was run with the channel dredged or not dredged. Any increase of pollutant concentration in the Bay after 2017 is unlikely to be due to the dredging.

\section{Discussion}

The aim of this study was to understand the fate of potential pollutants and flushing time of Port Vila Bay and in Erakor Lagoon systems, and the impact of wastewater discharge on water quality, inclusive of projected sea level rise and related climate variability. This in turn required a detailed understanding of the dominant circulation patterns that drive key processes and how circulation in the lagoons and bay is affected by waves, water levels, wind or buoyancy forcing.

\subsection{Microbial contamination}

Microbial contamination had already been recorded in Vila Bay at levels that failed the international bathing water standards (Devlin et al., 2020). The sewage contamination in Vila Bay (Devlin et al., 2020) is a concern to human health particularly with the poor flushing found in the Bay.

However, the water contamination was unknown in Erakor Lagoon system. We collected samples within Erakor Lagoon system to detect and quantify micro-organisms indicators of potential sewage contamination that could impact public health (EPA Office of Water, Office of Science and Technology, Health and Ecological Criteria Division, 2015). E. coli was used as an indicator of faecal contamination and the contamination by wastewater. These analyses were used in conjunction with the results from the calibrated numerical model on residence time. To our knowledge, this is the first study that has assessed $E$. coli on a regular basis in the Erakor Lagoon system and then developed a numerical model of Erakor Lagoon to estimate the flushing time.

We found an increase of $E$. coli in the lagoon system based on the samples collected from October 2019 to June 2020 compared to the samples collected in May 2019. E. coli concentrations were found to 

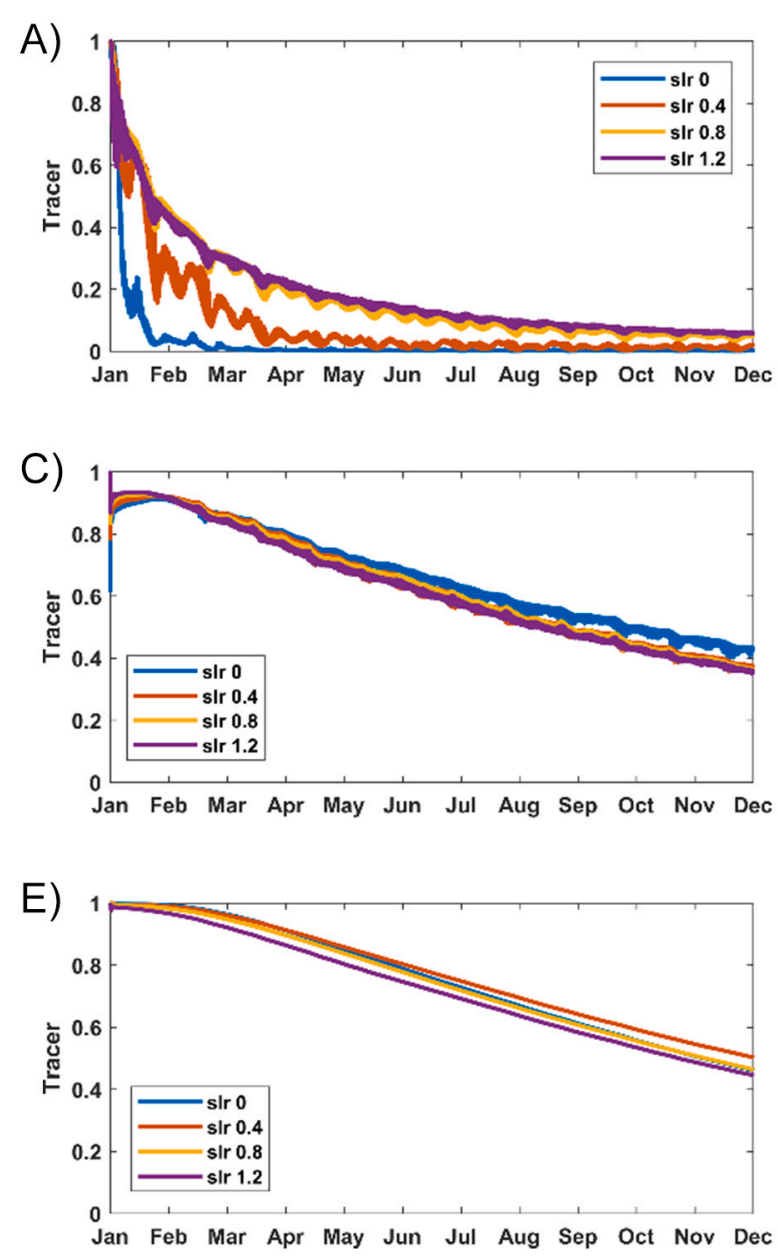
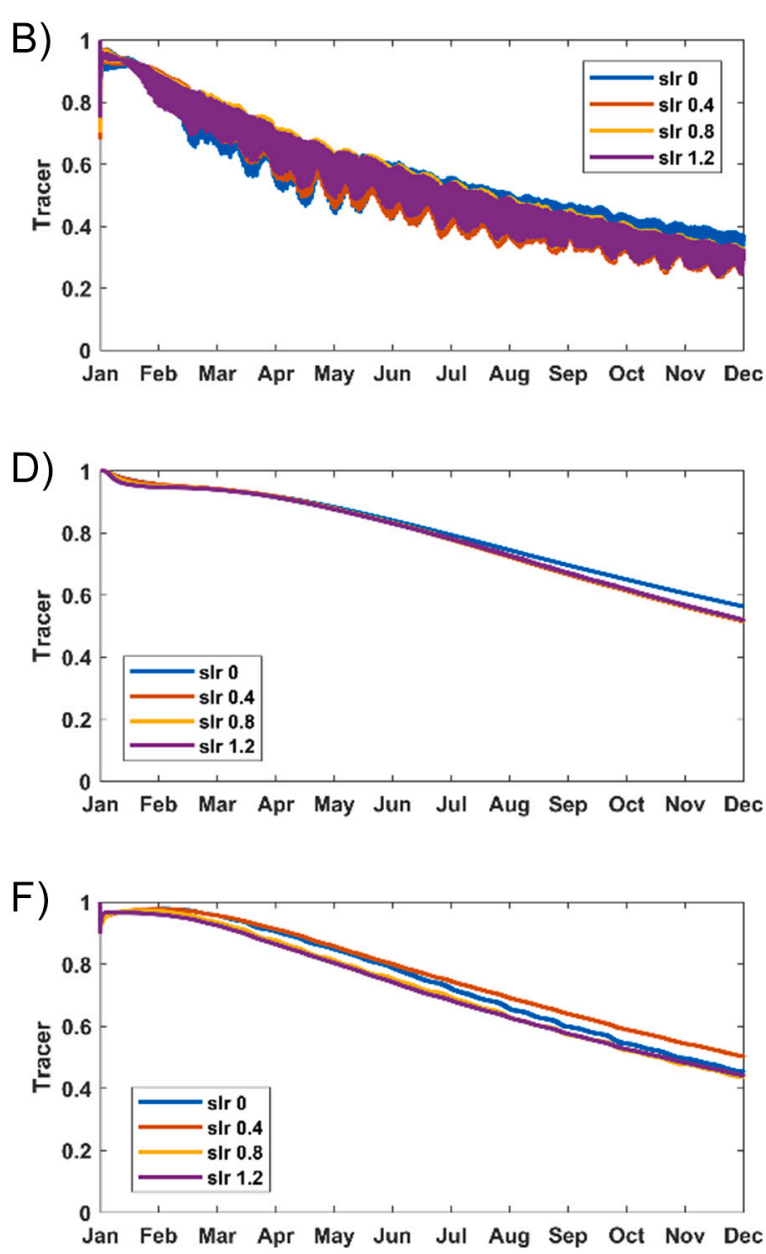

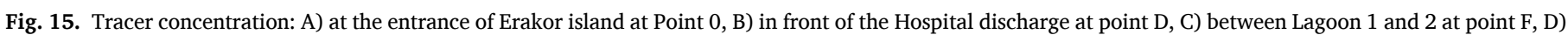

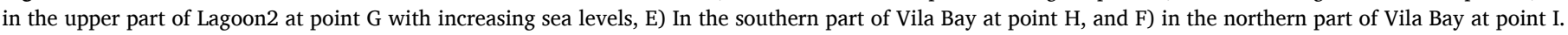
Points 0, D, F, G, H and I are given in Fig. 1.

exceed the level deemed safe health standard for recreational activities (esdat, 2000; Moreno et al., 2019) in most of the locations collected. These results are consistent with the poor flushing time found for the lagoon system. They are also consistent with observations from the Department of Environmental Protection and Conservation of the Government of Vanuatu, 2011 reporting and a substantial reduction in water quality in the lagoons relative to the open ocean.

At the entrance of the whole lagoon system (Point 0) samples collected on the beaches were found to have a lower concentration of E. coli. This is to be expected given this location's better water circulation and flushing. Water level ranges were found to diminish rapidly in the upstream part of Erakor, resulting in the ebb tide being insufficient to flush the whole system at once.

As most of the samples were collected during spring tides, a better understanding of the variations with tide, wave and wind and the other climate parameters including rain, would be gained from sampling E. coli over a longer time period. It would be helpful to collect both spring tide and average tide occurring at the quarter moon.

\subsection{Flushing time using numerical model}

The water exchange between the lagoons within the Erakor Lagoon system was studied and the residence times were calculated with varying parameters of waves, wind and sea level. The presence of waves helps to flush pollutants at the entrance of the lagoon system up to the half of Erakor 2 where a tourist resort is located. In the upstream part of the lagoon mixing is more sluggish resulting in an increase in pollution concentrations, compared to downstream where nutrients are mixed by waves and currents. Wave parameters do not significantly vary through the year, but larger waves are noticed during the dry season (Faivre et al., 2019). Therefore, it is likely to expect better flushing during the dry season than the wet season with smaller waves more likely in the period of December-February (Fig. 3). This result agrees with findings from Graham et al. (2020) which showed that high coastal concentration of pollutants is most likely during the wet season in Vila Bay.

The effect of wind produced a lower residence time in the southern part of the lagoon system and in Vila Bay. The exchange of the water in Vila Bay with the rest of Mele Bay is increased with wind impacts as is the northern part of the Erakor Lagoon system (Erakor 3). Only the tide and wind were shown to play a role in the residence time of the rest of the lagoon system. As low rates of water movement were found in Erakor 3 , any pollutants released in this section will not reach the ocean before the end of a harmonic tidal cycle (29 days) and are likely to remain in the Erakor 3 Lagoon. This implies that pollutants released into the northern part of the Erakor lagoon system and from the land in Vila Bay, are likely to be accumulated in the lagoon system. These results explain the poor water quality results found in the Erakor Lagoon system and in Vila Bay (Devlin et al., 2020).

The results highlight the risk of water quality issues from pollutants released in the upstream part of the lagoon systems; the furthest point from the ocean. Five high risk wastewater treatment plants in Port Vila have been identified including the Port Vila Central Hospital (upstream of Erakor 2, Iririki Island Resort (Vila Bay), Le Lagon Resort (entrance to the lagoon system), le Meridian Resort (Vila Bay) and the University of 

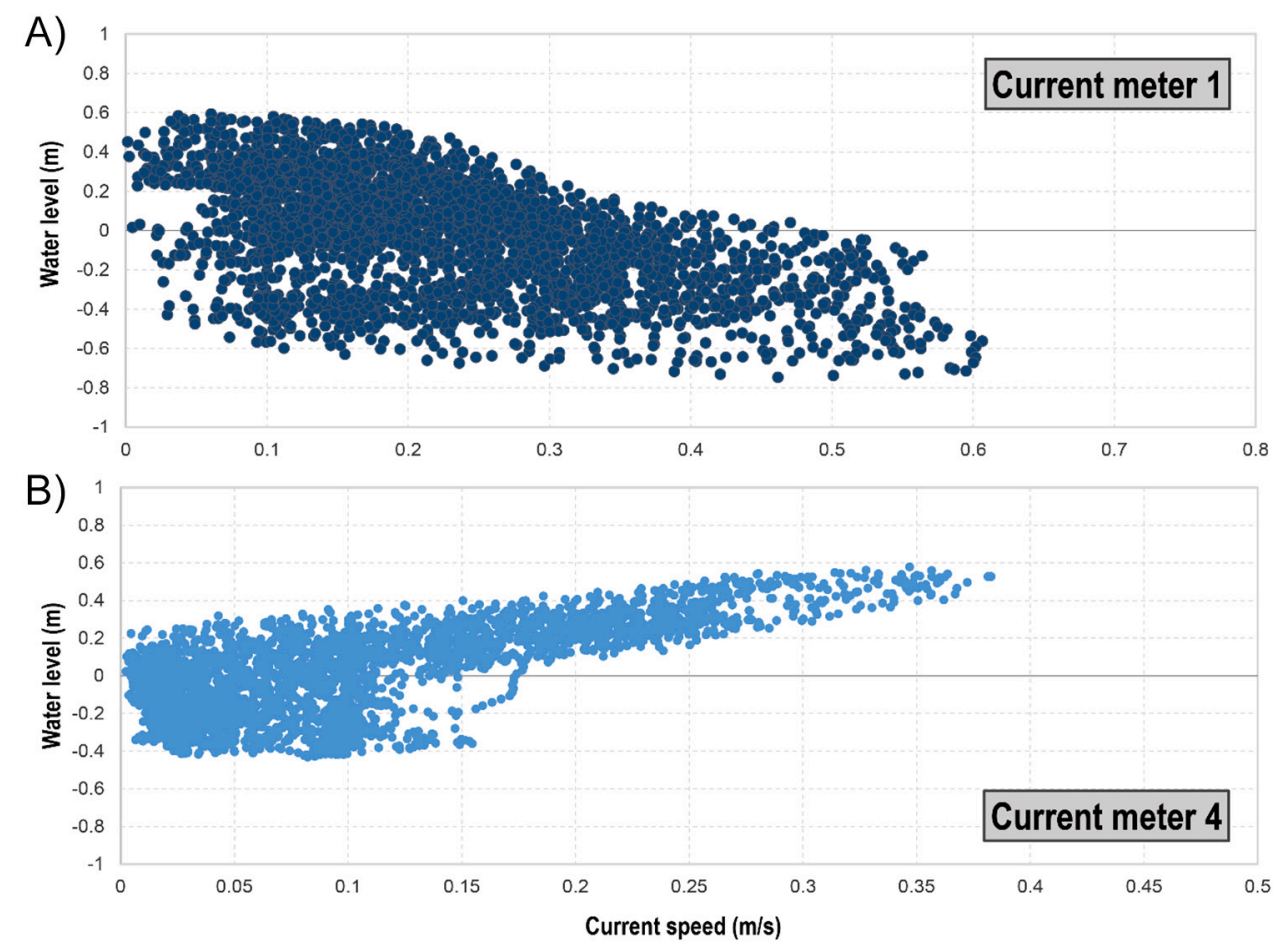

Fig. 16. Correlation between water levels and current speed within the lagoon, at the entrance A) (current meter 1) and at the entrance of Lagoon 2 B) (current meter 4).

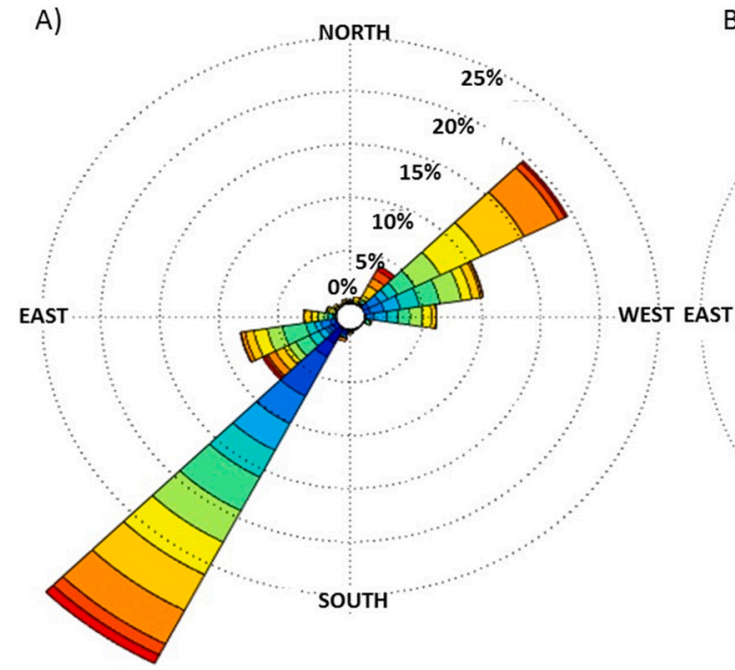

B)

B) NONTH

Fig. 17. Current direction with water level: A) current meter 1 and B) current meter 4).

South Pacific (upstream of Erakor 2) (SOPAC, 2007). The discharge from the hospital plant is monitored by UNELCO, a private company supplying electricity and water in Vanuatu. However, no monitoring data are publicly available (Department of Environmental Protection and Conservation of the Government of Vanuatu for the Asian Development Bank, 2011). Generally, pollutants released from hospitals include a variety of components such as pharmaceutical residues including antibiotics, detergents, endocrine disruptors and pathogens (Kumari et al., 2020).

Due to the poor flushing time found in this study, both the health of communities and that of the coral reef health, are likely to be impacted by pollutants released into the lagoon. Over the summer, increased runoff, and weaker winds (Fig. 3) are likely to increase the residence time of pollutants in the lagoon. It can also be expected that their surface concentration will increase due to less mixing (Graham et al., 2020), especially in Vila Bay where waters are deeper than the Erakor Lagoon.

Model simulations suggest an increase in sea levels would result in a decrease in the flushing time of the waters up to the upper part of Erakor 2 around the hospital discharge. In Erakor 3, this trend is reversed. In addition, climate change projections are likely to increase the residency time of a pollutant in the lagoon system due to increasing rainfall during the wet season (Graham et al., 2020), decreasing of the incidence of drought under the high emission scenario in Vanuatu (Clarke et al., 2011; Whetton et al., 2012) and from increasing sea levels.

The model results suggested that the flushing time in Vila Bay was not changed by previous dredging. However, we did not investigate the impact of dredging Erakor Lagoon or altering the dimension of the channel's inlet. This is a management issue that warrants further 


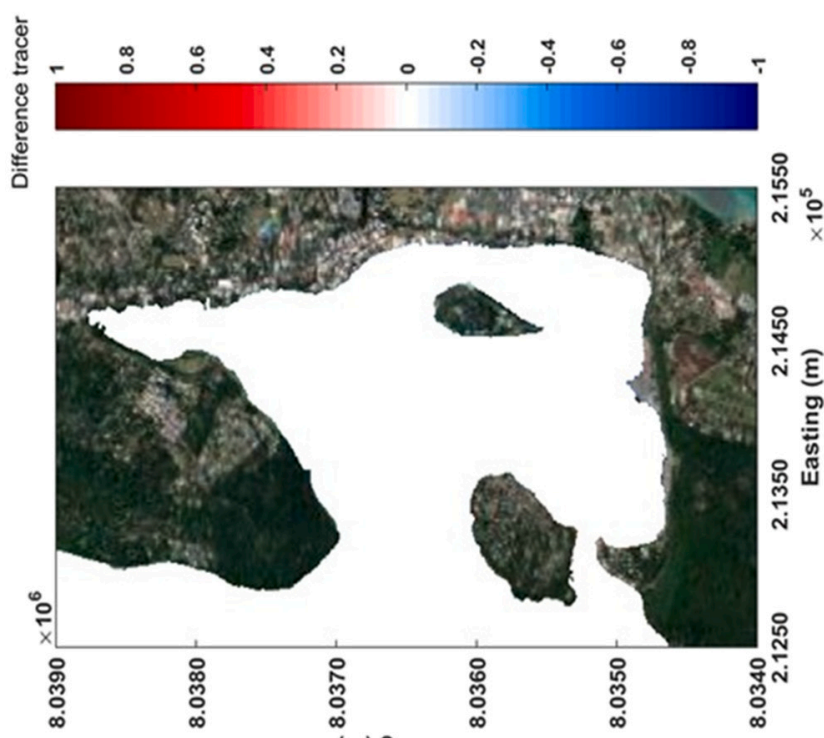

(u) 6u!чนนON

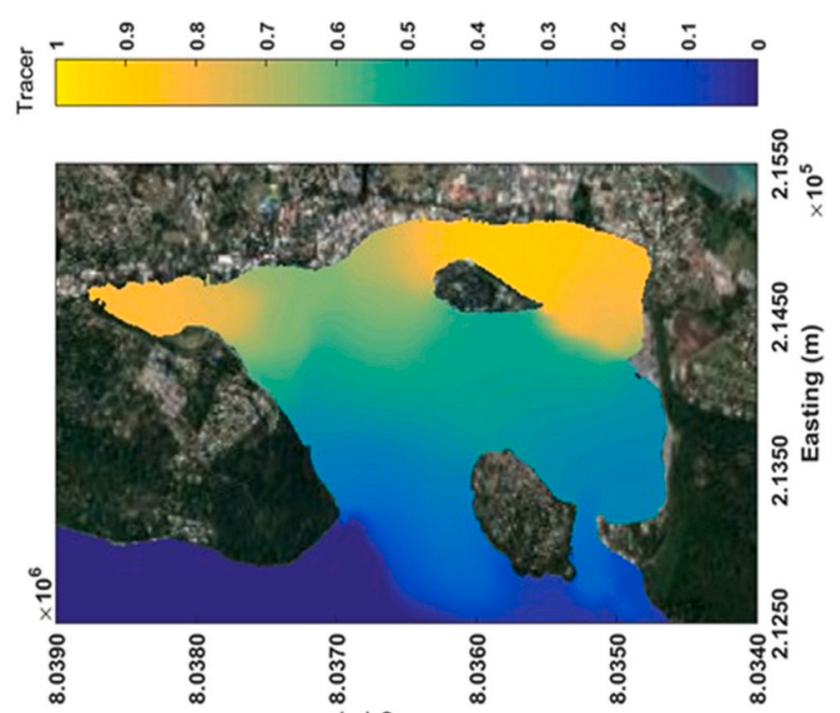

(u) 6u!̣น०N

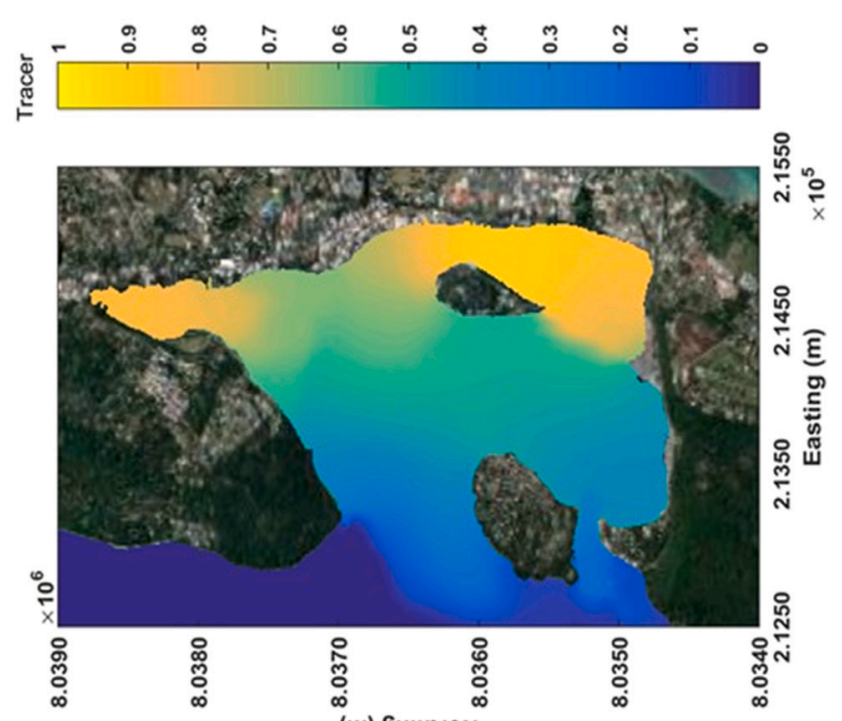

(u) 6u!̣чนоN investigation and further application of 3D numeric models would also increase understanding pollutant dispersion and management of the wastewater The 2-D approach used here assumes water bodies are wellmixed. This assumption is likely valid in the Erakor Lagoon system due to its shallow waters, where little stratification is to be expected. Vila Bay, however has deeper waters, and it would be necessary to monitor the water column to determine the validity of this assumption. Furthermore, for contaminant dispersion studies, the 2D model assumes contaminants are fully mixed and are not concentrated at the surface or a particular depth. Additional monitoring is therefore needed to provide observational data for modelling the rate of decay for pollutants in the Lagoon system and Vila Bay. Long-term monitoring of the Erakor Lagoon system, as is done for Vila Bay (Devlin et al., 2020) will help improve understanding of the impacts on water quality parameters of proposed developments and a rapidly changing climate. Long-term water quality monitoring provides the data needed for modelling short and long-term temporal and within-lagoon spatial variability.

Further work is needed to investigate pollutant dispersion. Additional data collection would increase understanding of processes in this lagoon system (Blacka and Drummond, 2019; Gutierres et al., 2016) with climate patterns (Nayeb et al., 2014).

\subsection{Improve management of coastal waters in SIDS}

The model was able to provide useful insights into the hydrodynamics of the Erakor Lagoon system and Vila Bay Harbor, with the former being particularly understudied. The bathymetry, waves and wind were found to play an important role in the circulation pattern and residence time of a pollutant. The improved understanding of the role of tides, waves and climate change can assist decision makers in meeting growing water management challenges.

The poor water exchange found in the Lagoon system has implications for water management (Mudge et al., 2008). It is not likely to be safe to release any pollutants in these areas at any phase of the tide due to the low water exchange with the rest of the Bay. Uncontrolled wastewater discharge in the Lagoon system decreases water quality and increases the health risks for people. Treatment before releasing wastewater is therefore crucial and it is strongly recommended that nontreated wastewater be prevented from being discharged. Increasing volumes of wastewater discharge are anticipated due to the growing urban population (Vanuatu National Statistics Office, 2021).

Regular maintenance of existing sanitation facilities is a critical pollution control measure which require particular attention during summer when wind is lower and runoff increases. Oversight of this maintenance is the responsibility of the relevant agencies (Department of Environmental Protection and Conservation of the Government of Vanuatu for the Asian Development Bank, 2011). Development of wastewater discharge standards from contaminated sources are needed to avoid high pollution in the water system (Poustie and Deletic, 2014; Zheng et al., 2020). As the driving factors of water environment pressure are population size and urbanisation, these standards need to be accompanied by industrial optimisation, technological upgrading and increase management (Zhang et al., 2021). A key task is to determine the maximum permissible concentrations/loads of pollutants in wastewater discharged in the lagoon to maintain the good quality of the water body (Preisner et al., 2020). An integrated approach is needed (Sad et al., 2020) that considers all factors affecting the water quality. For example, drainage systems in Port Vila are designed for the runoff response to the rainfall of a 1 in 5-year storm (Department of Environmental Protection and Conservation of the Government of Vanuatu for the Asian Development Bank, 2011). Knowing the storm frequency is therefore crucial to designing drainage flow. Another concern, would be the drainage capacity in Port Vila with growing population.

Another relevant management point which is also relevant for other islands in the South Pacific, is that during monitoring, mangroves were found on the edge of the eastern part of the lagoon system where local 
communities live. However, they were absent in front of infrastructure on the western part on the lagoon. The coastal zone of many South Pacific islands faces such development pressures from an expanding tourist sector. However, mangroves and seagrass meadows provide important ecosystem services including filtering pollutants, nutrients and sediments carried from wastewater (McEvoy et al., 2017; Taillardat et al., 2020; Ouyang and Guo, 2016) which help keep lagoon systems in good condition. Khambete and Shakwala (2010) demonstrated that mangrove acts as a natural wetland for treatment of domestic wastewater discharged, retaining excess nutrients and some pollutants (Knox et al., 2008). There is a need of increasing public awareness (Katupotha, 2016) and coastal planners to promote conservation of mangrove habitats to improve water management. The management and restoration of mangroves would play a critical role in sustaining health of coastal ecosystem including coral reef through water quality improvement (Adame et al., 2019).

\section{Conclusion}

This study provides new information on the residence time of pollutants in the Erakor Lagoon systems and Port Villa Bay. The results highlight the influence of wind, waves and water level in their patterns of circulation. This information can inform planning and management to reduce marine pollution of the lagoon and prevent future pollution associated with land-based activities and associated developments. Similar studies are needed throughout the SIDS. These results are a first step in the development of a more comprehensive, long-term monitoring system. Additional monitoring is needed to support improved water quality management and decision making in coastal ecosystems that provides significant benefits for local communities and the tourist sector.

\section{CRediT authorship contribution statement}

Conception and design of the study: Gaëlle Faivre.

Acquisition of data: Gaëlle Faivre, Erie Sami, Dr. Krishna Kumar Kotra, Jim Aimbie, Michael Maniel.

Analysis and/or interpretation of data: Gaëlle Faivre, Prof. Rodger Tomlinson, Prof. Hong Zhang, Dr. Guilherme Vieira da Silva, Prof. Brendan Mackey.

Drafting and editing the manuscript: Gaëlle Faivre, Prof. Rodger Tomlinson, Prof. Hong Zhang, Prof. Brendan Mackey.

Draft revisions: Gaëlle Faivre led draft revisions, with all authors contributing to the revision process.

\section{Declaration of competing interest}

The authors declare that they have no known competing financial interests or personal relationships that could have appeared to influence the work reported in this paper.

\section{Acknowledgements}

The authors are grateful to the Department of Water Resources of Vanuatu, the Office of the Maritime Regulator, and the University of South Pacific for supporting data collection in this study. Data collection was enabled by the support and involvement of the local communities and customary owners of the lagoons and associated land. This research was undertaken with the approval of a research agreement between the Vanuatu National Cultural Council and Griffith University (May 17, 2018). The research was supported by a grant from a charitable organisation which neither seeks nor permits publicity for its efforts.

We thanks two anonymous reviewers whose comments and suggestions greatly improve this paper. We also thanks Ana Paula da Silva for helping us with some figures formatting.

\section{References}

Adame, M.F., Roberts, M.E., Hamilton, D.P., Ndehedehe, C.E., Reis, V., Lu, J., Griffiths, M., Curwen, G., Ronan, M., 2019. Tropical coastal wetlands ameliorate nitrogen export during floods. Front. Mar. Sci. 6, 671.

Aquagenx, 2021. Aquagenx ${ }^{\circledR}$ CBT EC TC (Compartment Bag Test) Most Probable Number (MPN) Kit Instructions for Use: 1:10 Dilution for Recreational and Surface Waters. https://www.aquagenx.com/wp-content/uploads/2021/04/1-10-DilutionInstructions-CBT-ECTC-MPN-April2021.pdf.

Blacka, M.J., Drummond, C.D., 2019. Measurements and hydrodynamic analysis of a complex fringing reef and lagoon system. In: Australasian Coasts and Ports 2019 Conference, pp. 346-353.

Boateng, I., 2010. Spatial Planning in Coastal Regions: Facing the Impact of Climate Change. FIG Commission 8 Working Group 8.4, ISBN 978-87-90907-90-7.

Brodie, J., Wolanski, E., Lewis, S., Bainbridge, Z., 2012. An assessment of residence times of land-sourced contaminants in the Great Barrier Reef lagoon and the implications for management and reef recovery. Mar. Pollut. Bull. 65 (4-9), 267-279. https://doi. org/10.1016/j.marpolbul.2011.12.011, 0025-326X.

Carter, R., 1990. Hydraulic and Water Quality Studies, Erakor Lagoons and Port Vila Harbour, Vanuatu. SOPAC Technical Report, 117.

Clarke, J.M., Whetton, P.H., Hennessy, K.J., 2011. Providing application-specific climate projections datasets: CSIRO's Climate Futures Framework. In: 19th International Congress on Modelling and Simulation, Perth, Australia, 12-16 December 2011. htt p://mssanz.org.au/modsim2011.

Davis, R., Fitzgerald, D.M., 2004. Beaches and Coasts. Blackwell Science Ltd., Malden, MA.

Deltares, 2014. Delft3D-WAVE, Simulation of Shortcrested Waves With SWAN. User Manual, Version 3.05.34160.

Department of Environmental Protection and Conservation of the Government of Vanuatu for the Asian Development Bank, 2011. Republic of Vanuatu: Port Vila Urban Development Project. Initial Environmental Examination.

Department of Geology, Mines \& Water Resources, Government of Vanuatu, 2018. Vanuatu National Water Strategy 2008-2018.

Devlin, M., Smith, A., Graves, C.A., Petus, C., Tracey, D., Maniel, M., Hooper, E., Kotra, K., Samie, E., Loubser, D., Lyons, B., 2020. Baseline assessment of coastal water quality, in Vanuatu, South Pacific: insight gained from in-situ samplings. Mar. Pollut. Bull. 160 (2020), 111651.

DGMWR, 2008. http://extwprlegs1.fao.org/docs/pdf/van176920.pdf.

Done, T.J., Navin, K.F., 1990. Vanuatu Marine Resources: Report of a Biological Survey. A Project of the Australian International Development Assistance Bureau. Australian Institute of Marine Science, Townsville, Australia, 272pp.

Dumas, F., et al., 2012. Tidal flushing and wind driven circulation of Ahe atoll Lagoon (Tuamotu Archipelago, French Polynesia) from in situ observations and numerical modelling. Mar. Bull. Pollut. https://doi.org/10.1016/j.marpolbul.2012.05.041.

EPA Office of Water, Office of Science and Technology, Health and Ecological Criteria Division, 2015. Review of Coliphages as Possible Indicators of Fecal Contamination for Ambient Water Quality. 820-R-15-098.

Faivre, G., Viera da Silva, G., Ware, D., Tomlinson, R., Mackey, B., Zhang, H., 2019. Seasonal, extremes and wave climate variability of the southwest of Efate Island, Vanuatu. In: Australasian Coasts and Ports 2019 Conference Future Directions From 40 [degrees] S and Beyond, Hobart, 10-13 September 2019, 2019. Engineers Australia, Hobart, pp. 381-387.

Garschagen, M., Hagenlocher, M., Comes, M., Dubbert, M., Sabelfeld, R., Lee, Y.J., Grunewald, L., Lanzendörfer, M., Mucke, P., Neuschäfer, O., Pott, S., Post, J., Schramm, S., Schumann-Bölsche, D., Vandemeulebroecke, B., Welle, T., Birkmann, J., 2016. World Risk Report 2016. World Risk Report, Bündnis Entwicklung Hilft and UNU-EHS.

GEBCO Compilation Group, 2020. GEBCO 2020 Grid. https://doi.org/10.5285/ a29c5465-b138-234d-e053-6c86abc040b9.

Gheuens, J., Nagabhatla, N., Perera, E.D.P., 2019. Disaster-risk, water security challenges and strategies in small island developing states (SIDS). Sustainable water management strategies: climate change induced disaster risk. Water 11 (4), 637.

Graham, J.A., Haverson, D., Bacon, J., 2020. Modelling pollution dispersal around Solomon Islands and Vanuatu. Mar. Pollut. Bull. 150, 110589.

Graves, C.A., Powell, A., Stone, M., Redfern, F., Biko, T., Devlin, M., 2021. Marine water quality of a densely populated Pacific atoll (Tarawa, Kiribati): cumulative pressures and resulting impacts on ecosystem and human health. Mar. Pollut. Bull. 163, 111951.

Gronewold, A.D., Sobsey, M.D., McMahan, L., 2017. The compartment bag test (CBT) for enumerating fecal indicator bacteria: basis for design and interpretation of results. Sci. Total Environ. 587-588, 102-107.

Guo, Q., , Member ASCE, Lordi, G.P., 2000. Method for quantifying freshwater input and flushing time in estuaries. J. Environ. Eng. 126 (7), 675-683.

Gutierres, F., Teodoro, A.C., Reis, E., Neto, C., Costa, J.C., 2016. Remote sensing technologies for the assessment of marine and coastal ecosystems. In: Coastal Research Library, 13, pp. 69-104. Cited 6 times.

Hall. https://www.hallcontracting.com.au/about/news/channel-dredging-completed-insouth-paray-bay. (Accessed 29 August 2021).

Hart, J.D., Blackwood, A.D., Noble, R.T., 2020. Examining coastal dynamics and recreational water quality by quantifying multiple sewage specific markers in a North Caroline estuary. Sci. Total Environ. 747, 141124.

Heintz, H., Kirch, L., Kuppers, B., Mann, H., Mischo, F., Mucke, P., Pazdzierny, T., Prutz, R., Radtke, K., Strube, F., Weller, D., 2018. World risk report 2018. ReliefWeb. https://reliefweb.int/sites/reliefweb.int/files/resources/WorldRiskReport-2018.pdf 
Katupotha, J., 2016. Mangroves in lagoon ecosystems: a neglected habitat in Sri Lanka. Wildlanka 4 (3), 079-105.

Khambete, A.K., Shakwala, N.J., 2010. Role of mangroves on domestic wastewater discharge: case study at Jamnagar costal region, India. In: ICBEE 2010-2010 2nd International Conference on Chemical, Biological and Environmental Engineering, Proceedings, art. no. 5651619, pp. 359-362.

Knox, A.K., Dalhlgren, R.A., Tate, K.W., Atwill, E.R., 2008. Efficacity of natural wetlands to retain nutrient, sediment and microbial pollutants. J. Environ. Qual. 37 (5), 1837-1846. https://doi.org/10.2134/jeq2007.0067.

Komugabe-Dixson, A.F., S.E. de Ville, N., Trundle, A., McEvoy, D., 2019. Environmental change, urbanisation, and socio-ecological resilience in the Pacific: community narratives from Port Vila, Vanuatu. Ecosyst. Serv. ISSN: 2212-0416 39, 100973 https://doi.org/10.1016/j.ecoser.2019.100973.

Kumari, A., Maurya, N.S., Tiwari, B., 2020. Hospital wastewater treatment scenario around the globe. Curr. Dev. Biotechnol. Bioeng. 549-570 https://doi.org/10.1016/ B978-0-12-819722-6.00015-08.

Li, H., 2010. Concepts and Applications of Water Transport Time Scales for Coastal Inlet Systems. US Army Corps of Engineers. Coastal and Hydraulics Engineering Technical Note.

Lowe, R.J., Hart, C., Pattiaratchi, C.B., 2010. Morphological constraint to wavelengdriven circulation in coastal fringing reef-lagoon systems: a numerical study. J. Geophys. Res. 115, C0902.

Mackey, B., Ware, D., 2018. Limits to capital works adaptation in the coastal zones and Islands: Lessons for the Pacific. In: Filho, Walter Leal, Nalau, Johanna (Eds.), Limits to Climate Change Adaptation. Springer, Cham, pp. 301-323.

Matso, K., 2018. Flushing Time Versus Residence Time for the Great Bay Estuary, 413. PREP Reports \& Publications. https://scholars.unh.edu/prep/413.

McEvoy, D., de Ville, N., Komugabe-Dixson, A., Trundle, A., 2017. Greater Port Vila. Social Mapping and Analysis of Ecosystem Use, Apia, Samoa: SREP.

Moreno, H.S., Bolívar-Anillo, H.J., Soto-Varela, Z.E., Aranguren, Y., Píchon Gonzaléz, C., Villate Daza, D.A., Anfuzo, G., 2019. Microbiological water quality and sources of contamination along the coast of the Department of Atlántico (Caribbean Sea of Colombia). Preliminary results. Mar. Pollut. Bull. 142, 303-308. https://doi.org/ 10.1016/j.marpolbul.2019.03.054, 0025-326X.

Mudge, S.M., Icely, J.D., Newton, A., 2008. Residence times in a hypersaline lagoon: using salinity as a tracer. J. Estuar. Coast. Shelf Sci. 77 (2), 278-284.

Nayeb, H., Torabian, A., Mehrdadi, N., 2014. Selecting the optimal urban wastewater treatment process in the various climates by using analytic hierarchy process (AHP). J. Environ. Stud. 40 (3), 787-799.

Nurse, L.A., McLean, R.F., Agard, J., Briguglio, L.P., Duvat-Magnan, V., Pelesikoti, N., Tompkins, E., Webb, A., 2014. Small islands. In: Barros, V.R., Field, C.B., Dokken, D. J., Mastrandrea, M.D., Mach, K.J., Bilir, T.E., Chatterjee, M., Ebi, K.L., Estrada, Y.O., Genova, R.C., Girma, B., Kissel, E.S., Levy, A.N., MacCracken, S., Mastrandrea, P.R., White, L.L. (Eds.), Climate Change 2014: Impacts, Adaptation, and Vulnerability. Part B: Regional Aspects. Contribution of Working Group II to the Fifth Assessment Report of the Intergovernmental Panel on Climate Change. Cambridge University Press, Cambridge, United Kingdom and New York, NY, USA, pp. 1613-1654.

Ouyang, X., Guo, F., 2016. Paradigms of mangroves in treatment of anthropogenic wastewater pollution. Sci. Total Environ. 544, 971-979.

Pacific-Australia Climate Change Science and Adaptation Planning Program, 2013. Current and future climate of Vanuatu. In: Climate Variability, Extremes and Change in the Western Tropical Pacific: New Science and Updated Country Reports (2014) and Climate Change in the Pacific: Scientific Assessment and New Research. Volume 1: Regional Overview. Volume 2: Country Reports (2011).

Poustie, M.S., Deletic, A., 2014. Modeling integrated urban water systems in developing countries: case study of Port Vila, Vanuatu. Ambio 43 (8), 1093-1111.
Preisner, M., Neverova-Dziopak, E., Kowalewski, Z., 2020. An analytical review of different approaches to wastewater discharge standards with particular emphasis on nutrients. Environ. Manag. 66 (4), 694-708.

Sad, S.M.K., Casal-Campos, A., Fu, G., Farmani, R., Ward, S., Butler, D., 2020. Strategic planning of the integrated urban wastewater system using adaptation pathways. Water Res. 182, 116013.

Sofarocean, 2021. https://www.sofarocean.com/products/spotter. (Accessed 19 May 2021).

SOPAC, 2007. National Integrated Water Resource Management Diagnostic Report, Vanuatu. Report 648. IWRM Diagnostic Report Vanuatu.

Sous, D., Devenon, J.L., Blanchot, J., Pagano, M., Chevalier, C., 2017. Circulation patterns in a channel reef-lagoon system, Ouano lagoon, New Caledonia. Elsevier, 2017 Estuar. Coast. Shelf Sci. 196, 315-330. ff10.1016/j.ecss.2017.07.015ff. ffhal $01566395 f$.

Spencer, D., Lemckert, C.J., Yu, Y., Gustafson, J., Lee, S.Y., Zhang, H., 2014. Quantifying dispersion in an estuary: a Lagrangian drifter approach. In: Green, A.N., Cooper, J.A. G. (Eds.), Proceeding 13th International Coastal Symposium (Durban, South Africa), Journal of Coastal Research, Special Issue No. 70, pp. 029-034, 0749-0208.

SPREP, 2016. Cleaner Pacific 2025: Pacific Regional Waste and Pollution Management Strategy 2016-2025. SPREP, Apia, Samoa (2016)(68 p. 29 cm. ISBN: 978-982-040572-1 (print)).

Stauber, C., Miller, C., Cantrell, B., Kroell, K., 2014. Evaluation of the compartment bag test for the detection of Escherichia coli in water. J. Microbiol. Methods 99 (1), 66-70.

Taillardat, P., Marchand, C., Friess, D.A., Widory, D., David, F., Ohte, N., Nakamura, T., Van Vinh, T., Thanh-Nho, N., Ziegler, A.D., 2020. Respective contribution of urban wastewater and mangroves on nutrient dynamics in a tropical estuary during the monsoon season. Mar. Pollut. Bull. 160, 111652.

Thomas, A., Baptiste, A., Martyr-Koller, R., Pringle, P., Rhiney, K., 2020. Climate change and small island developing states. Annu. Rev. Environ. Resour. https://doi.org/ 10.1146/annurev-environ-012320-083355.

Tolman, H.L., 2009. User manual and system documentation of WAVEWATCH IIITM version 3.14. In: NOAA/NWS/NCEP/MMAB Technical Note 276, 194 pp Appendices.

Tseng, R.S., 2002. On the Dispersion and Diffusion Near Estuaries and Around Islands. Estuar. Coast. Shelf Sci. 54, 89-100.

United Nations, 2004. Is a special treatment of small island developing states possible?. In: United Nations Conference on Trade and Development, UNCTAD/LCD/2004/1.

United Nations, Department of Economic and Social Affairs, Population Division, 2019. World Population Prospects 2019: Highlights (ST/ESA/SER.A/423).

Vanuatu National Statistics Office (VNSO). https://vnso.gov.vu/index.php/en/.

Wang, Y., Ridd, P.V., Heron, M.L., Stieglitz, T.C., Orpin, A.R., 2007. Flushing time of solutes and pollutants in the central Great Barrier Reef lagoon, Australia. Mar. Freshw. Res. 58, 778-791.

Whetton, P., Hennessy, K., Clarke, J., et al., 2012. Use of representative climate futures in impact and adaptation assessment. Clim. Chang. 115, 433-442. https://doi.org/ 10.1007/s10584-012-0471-z.

Zari, M.P., Blaschke, P.M., Jackson, B., Komugabe-Dixson, A., Livesey, C., Loubser, D.I., Martinez-Almoyna Gual, C., Maxwell, D., Rastandeh, A., Renwick, J., Weaver, S., Archie, K.M., 2020. Devising urban ecosystem-based adaptation (EbA) projects with developing nations: a case study of Port Vila, Vanuatu. Ocean Coast. Manag. ISSN: 0964-5691 184, 105037 https://doi.org/10.1016/j.ocecoaman.2019.105037.

Zhang, Y., Sun, M., Yang, R., Li, X., Zhang, L., Li, M., 2021. Decoupling water environment pressures from economic growth in the Yangtze River Economic Belt, China. Ecol. Indic. 122, 107314.

Zheng, J., Kamal, M.A., Ullah, A., 2020. The direct and indirect effects of China's wastewater treatment service on urban household wastewater discharge. Growth Chang. 51 (3), 1380-1400. 